\title{
FIRST SYSTEMATIC INVESTIGATION OF ADULTS AND SECOND CHECKLIST OF CADDISFLIES (INSECTA, TRICHOPTERA) OF THE PLITVICE LAKES NATIONAL PARK WITH NOTES ON RESEARCH HISTORY, BIODIVERSITY, DISTRIBUTION AND ECOLOGY
}

\author{
Mladen Kučinić ${ }^{*}$, Ana Previšić ${ }^{1}$, Mladen Vajdić ${ }^{2}$, Monika Tunjić ${ }^{3}$, \\ Iva Minoci ${ }^{2}$, Sanja Žalac ${ }^{4}$, SANJa Sviben ${ }^{5}$, Ivan VučKović ${ }^{6}$, Maja \\ TRUPKOVIĆ $^{7}$ \& IVAN HABDIJA ${ }^{1}$
}

${ }^{1}$ Department of Biology (*Laboratory for Entomology), Faculty of Science, University of Zagreb, Rooseveltov trg 6, 10000 Zagreb, Croatia

${ }^{2}$ Croatian Natural History Museum, Demetrova 1, 10000 Zagreb, Croatia

${ }^{3}$ Center for Research and Knowledge Transfer in Biotechnology, Rockefellerova 10, 10000 Zagreb, Croatia

${ }^{4}$ Plitvice Lakes National Park, 53231 Plitvička jezera, Croatia

${ }^{5}$ Max Planck Institute of Colloids and Interfaces, Am Muehlenberg 1, 14476 Potsdam, Germany ${ }^{6}$ Elektroprojekt d.d., Civil and Architectural Engineering Department, Water Resources, Nature and Environmental protection, Alexandera von Humboldta 4, 10000 Zagreb, Croatia

${ }^{7}$ School of Medicine, University of Zagreb, Šalata 2, 10000 Zagreb, Croatia

Kučinić, M., Previšić, A., Vajdić, M., Tunjić, M., Mihoci, I., Žalac, S., Sviben, S., Vučković, I., Trupković, M. \& Habdija, I.: First systematic investigation of adults and second checklist of caddisflies of the Plitvice Lakes National Park with notes on research history, biodiversity, distribution and ecology. Nat. Croat., Vol. 26, No. 2., 225-260, Zagreb, 2017.

The Plitvice Lakes National Park is a unique area in the world with a great variety of aquatic habitats, including tufa barriers. UNESCO has protected this area since 1979. In this paper, detailed faunistic results of the first research on Trichoptera species conducted from 1997 to 2001 are shown. Sampling was done using both light and emergence traps, and 77 caddisfly species were determined using the two methods. Furthermore, a brief overview of the Trichoptera research history in the Plitvice Lakes area is given along with a detailed presentation of caddisfly fauna and an extended second checklist of Trichoptera species in the NP. In the Plitvice Lakes 89 Trichoptera species have been recorded so far. Flight periods are given for each species. Also, the reasons of such a high degree of Trichoptera biodiversity (the highest in Croatia) in the Plitvice Lakes are highlighted. A comparison of species assemblages collected from the 12 localities was made along with the comparison of Trichoptera fauna composition in different aquatic habitats in the Plitvice Lakes NP: springs, streams, lakes and tufa barriers.

Keywords: aquatic insects, caddisflies, Plitvice Lakes, biodiversity, ecology, nature protection, UNESCO, Croatia

Kučinić, M., Previšić, A., Vajdić, M., Tunjić, M., Mihoci, I., Žalac, S., Sviben, S., Vučković, I., Trupković, M. \& Habdija, I.: Prvo sistematsko istraživanje adulta i drugi popis tulara (Insecta, Trichoptera) za područje Nacionalnog parka Plitvička jezera s osvrtom na povijest istraživanja, bioraznolikost, rasprostranjenost i ekologiju. Nat. Croat., Vol. 26, No. 2., 225-260, Zagreb, 2017. 
Plitvička jezera jedinstveno su područje u svijetu s velikom raznolikošću slatkovodnih staništa od kojih se posebno ističu sedrene barijere. Ovo je područje pod zaštitom UNESCO-a od 1979. godine. Radom se prikazuju detaljni faunistički rezultati prvih sistematskih istraživanja tulara (Trichoptera, Insecta) na području Nacionalnog parka Plitvička jezera. Tulari su prikupljani metodama svjetlosnih i emergencijskih klopki u periodu od 1997. do 2001. godine, a zabilježeno je ukupno 77 vrsta. U radu se daje osvrt na povijest istraživanja tulara na području Nacionalnog parka, detaljan pregled faune tulara zabilježene na tome području te prikaz drugog, nadopunjenog popisa Trichoptera NP Plitvička jezera. Na području Nacionalnog Parka dosadašnjim je istraživanjima zabilježeno 89 vrsta tulara. Za sve vrste prikazuje se period leta te se ukazuje na razloge ovako velike bioraznolikosti tulara (najveća u Hrvatskoj) za područje Plitvičkih jezera. Izvršena je usporedba zabilježene faune na svim lokalitetima istraživanja (12 lokaliteta) na području Plitvičkih jezera, te usporedba sastava faune tulara na različitim slatkovodnim tipovima staništa na tome prostoru: izvorima, potocima, jezerima i sedrenim barijerama.

Ključne riječi: vodeni kukci, tulari, Plitvička jezera, biološka raznolikost, ekologija, zaštita prirode, UNESCO, Hrvatska

\section{INTRODUCTION}

The Plitvice Lakes National Park (NP) was designated as a UNESCO world natural heritage site in 1979. It is located in central mountainous part of Croatia in the region of Lika, situated in the Dinaric karst area (Fig. 1). It consists of a natural system of 16 oligotrophic barrage lakes (Fig. 1) where water flows from one lake to another over tufa barriers is the main factor in creating waterfalls and cascades (Ford \& PEDLEY, 1996). The splashing of water at the waterfalls stimulates extraction of carbon dioxide and sedimentation of calcium carbonate from the water. The overall result is the growth of tufa barriers (Figs. 6-7) which causes rising of the water level (Zwicker \& Rubinic, 2005) and formation of numerous karst aquatic habitats within springs (Fig. 2), streams (Fig. 3) and lakes (Figs. 4-5).

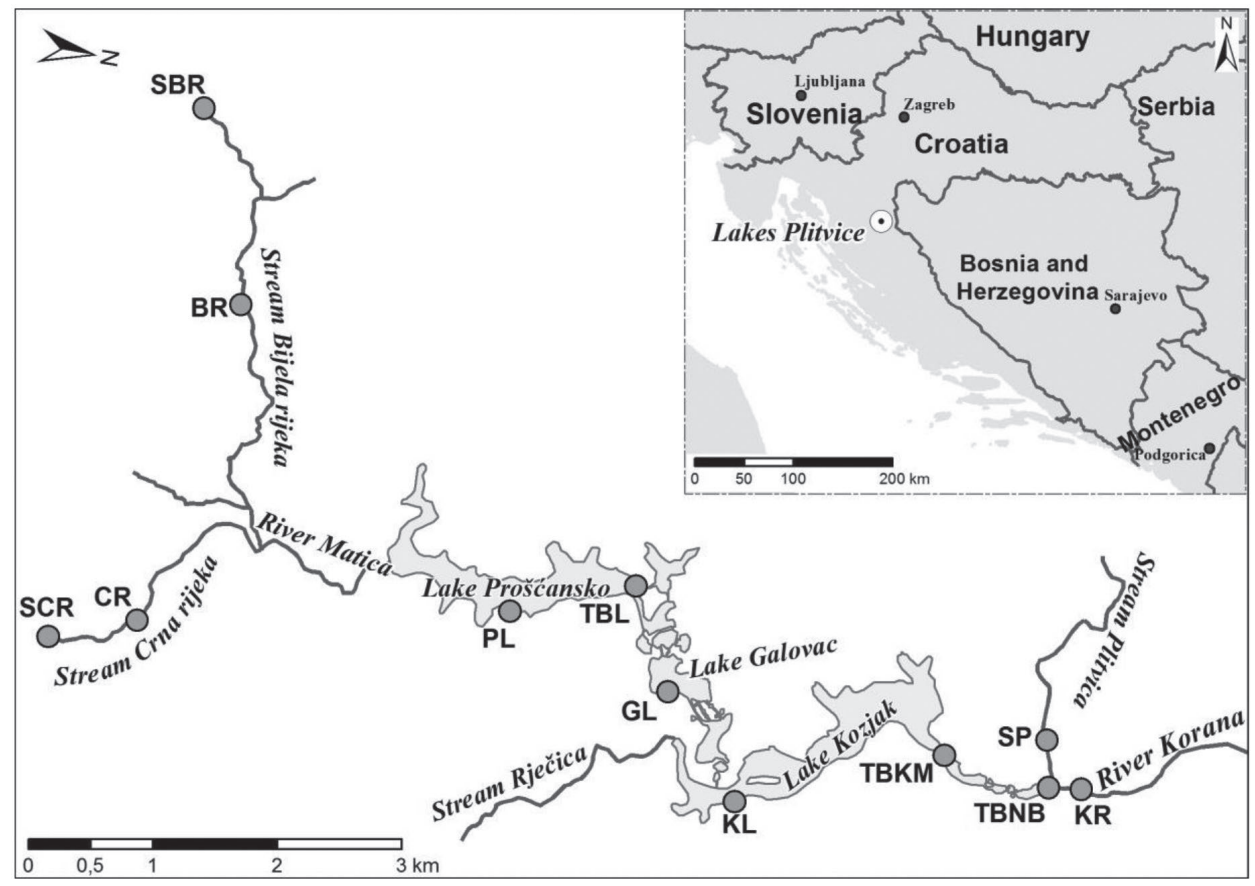

Fig. 1. Location of the Plitvice Lakes National Park in Croatia and position of 12 studied sampling sites: SBR - spring of Bijela rijeka stream, SCR - spring of Crna rijeka stream, BR - stream Bijela rijeka - middle part, CR - stream Crna rijeka - middle part, SP - stream Plitvica, KR - upper part of the river Korana, PL - Prošćansko Lake, GL - Galovac Lake, KL - Kozjak Lake, TBL - tufa barrier Labudovac, TBKM - tufa barrier Kozjak/Milanovac, TBNB - tufa barrier Novakovića Brod. 


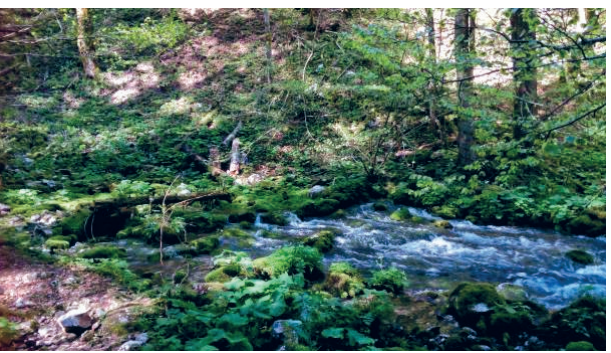

Fig. 2. Spring of the stream Crna rijeka.

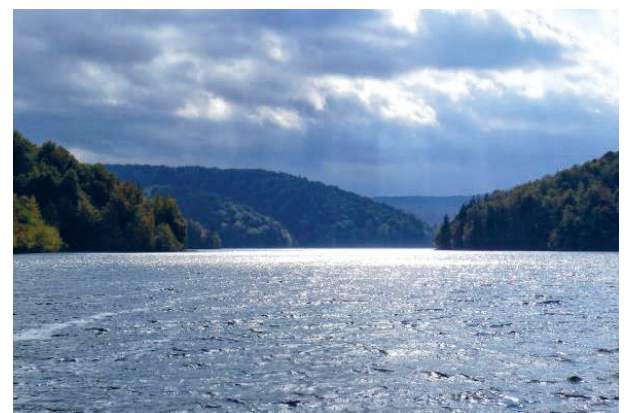

Fig. 4. Prošćansko Lake.

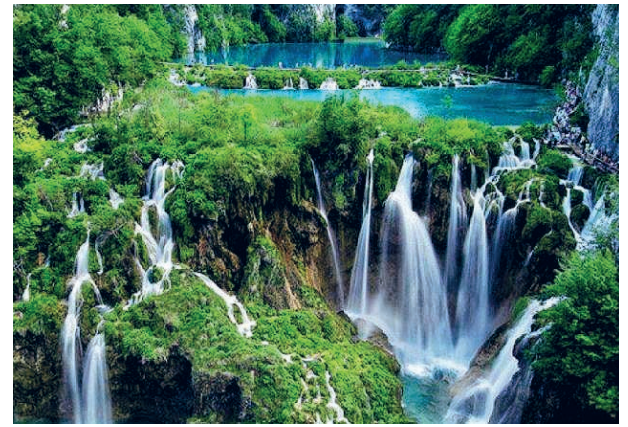

Fig. 6. Tufa barriers in lower lakes.

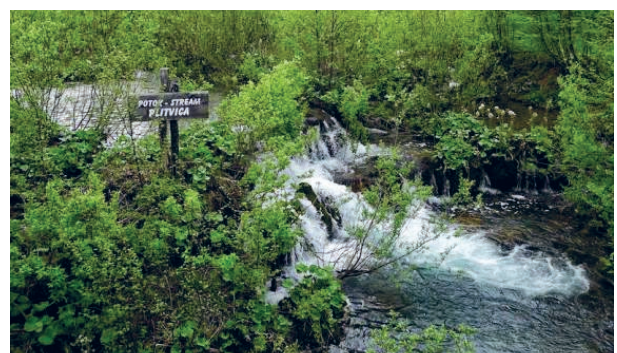

Fig. 3. Stream Plitvica - lower part.

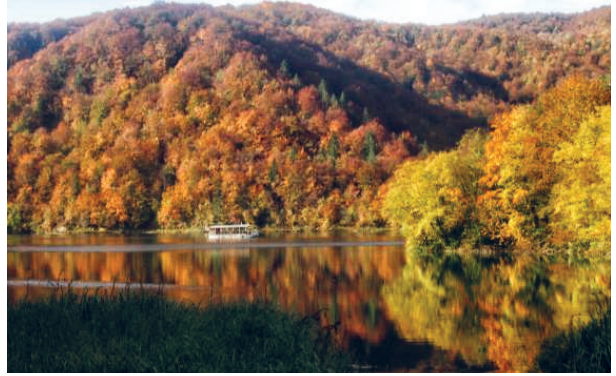

Fig. 5. Kozjak Lake.

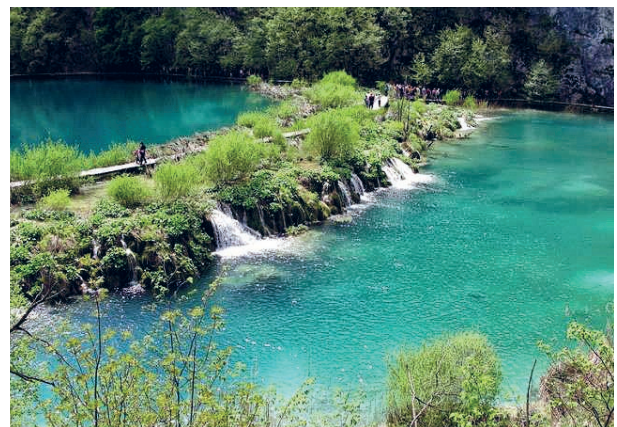

Fig. 7. Tufa barrier Novakovića Brod.

Tufa deposits are quite common, yet the development of the tufa dams that results in the differentiation of a river profile into a series of lakes and waterfalls is a rare phenomenon (GoLUBIć, 1969; Golubić et al., 2008). Nevertheless, there are some barrage-lake systems such as Ruidera Pools Natural Park (Spain), d'Immouzer and Ida du Tanane (Morocco), Turner Falls (USA), tufa springs in Queensland (Australia) and the above mentioned Plitvice Lakes NP (Croatia) (Ford \& Pedley, 1996). In a stream containing tufa dams organic matter will tend to accumulate resulting in tight spirals and delaying nutrient loss (Pentecost, 2005).

The Plitvice Lakes NP has been the subject of numerous faunistical, botanical, ecological and limnological studies that have been systematically conducted since the 1950s (e.g. KostiĆ-BRNEK \& BRNEKKostić, 1974; Habdija, 1989; Habdija et al., 1994, 2004; ŠEgulja \& HršAK, 1994; CAPut \& Plenković-Moraj, 2000; Primic-Habdija et al., 2001; Plenković-Moraj et al., 2002; HršAK et al., 2004; Lukač, 2004; ŠAšić, 2004; Miliša et al., 2006; ŠPoljar et al., 2007a; Popijač \& Sivec, 2009; Belančić et al., 2009; SERTIĆ Perić et al., 2011; Ivković et al., 2012, 2013a, 2013b, 2015; DražIna et al., 2013; Žutinić et al., 2014; MičETIĆ Stanković et al., 2015; Vilenica et al., 2017a, 2017b). The group of Trichoptera (caddisfly) was also partially involved in these studies (e.g. KučInIĆ, 2002; PrevišIć et al., 2009, 2013; ŠEMničKi et al., 2011, 2012). 
Caddisflies, along with other groups of aquatic insects, comprise one of the most abundant segments of aquatic fauna (Holzenthal et al., 2007) inhabiting all types of habitats (springs, streams, lakes, marshes, stream sediment accumulations and tufa barriers) which makes them very diverse and important objects of study within the research field of biodiversity of aquatic habitats. Until present, 14,548 species of caddisflies have been identified, divided in 616 genera and 49 families (Morse, 2017).

Systematic studies of the biodiversity, distribution, taxonomy and ecological features of caddisflies in the Plitvice Lakes NP have started 20 years ago by researchers at the Croatian Natural History Museum in Zagreb and Faculty of Science, University of Zagreb (e.g. KUčINIĆ, 2002; KučInIć \& MaLICKY, 2002; PREvišrć et al., 2007). In this paper we provide: 1) a brief overview of Trichoptera studies in the Plitvice Lakes NP; 2) an overview of faunistic data collected in 1997, during the first systematic study on Trichoptera (species, localities, number of collected specimens and collection dates); 3 ) an overview of unpublished faunistic obtained during 2000 and 2001 by the using of pyramid-type emergence traps (collection dates, number of males and females collected and localities without analyses published in paper PREvišić et al., 2007); 4) a revised checklist of Trichoptera species, including collection localities for each species; 5) an overview of the faunistic structures in different habitat types in the area of the Plitvice Lakes NP (springs, streams, lakes and tufa barriers); and 6) ecological characteristics of the Trichoptera fauna of the Plitvice Lakes NP (emergence features and flight periods).

\section{MATERIAL AND METHODS}

\section{Study area}

The Plitvice Lakes are a karstic hydrosystem with well defined hydrobiological (Golubić, 1969), hydrological (РetriK, 1958), mineralogical (STOFFers, 1975) and chemical (SRDoč et al., 1985; FrANČǏšKović-BILINSKI et al., 2004) properties. They are located in a mountainous part of Croatia (BERTIĆ et al., 2001) and have typical mountain climate features with cold winters and relatively hot summers. The main rainy period is in autumn and winter. Winters are very often accompanied by large amounts of snow and fog. Temperatures in summer can be as high as $30^{\circ} \mathrm{C}$ and in winter as low as $-25^{\circ} \mathrm{C}$ (MAKJANIĆ, 1972).

The Plitvice Lakes receive their water from two main streams, Bijela rijeka and Crna rijeka which discharge into the river Matica, and two tributaries, Rječica and Plitvica. The altitude of the area ranges between $720 \mathrm{~m}$ and $390 \mathrm{~m}$ a.s.l. The lake system is $9 \mathrm{~km}$ long and, due to geomorphological features, divided into twelve upper and four lower lakes (RiĐANović \& BožIČEvić, 1996).

\section{Fieldwork and sampling protocol}

We collected caddisflies in 12 localities in the Plitvice Lakes NP (Fig. 1); for each, we distinguished four types of habitats: springs (2 localities), streams (4 localities), tufa barriers (3 localities) and lakes (3 localities) (Figs. 2-7). Collecting was conducted from April to November in 1997 with light traps (mercury lamps, $300 \mathrm{~W}$ ) at all 12 localities for a period of one hour per locality (same catching effort in order to obtain comparable results). Collected specimens were deposited in small plastic containers containing $80 \%$ or $96 \%$ ethanol.

During 2000, four pyramid-type emergence traps (Fig. 8a) were placed in 4 different localities: Bijela Rijeka spring, Crna Rijeka spring, middle flow of Crna Rijeka and Labudovac tufa barrier. During 2001, one additional pyramid-type emergence trap was placed at the fifth locality: Kozjak/Milanovac tufa barrier (PREvišić et al., 2007). Each pyramid-type emergence trap was anchored to the bottom of the river and submerged $10-15 \mathrm{~cm}$ in the water. The emergence trap base dimensions were $45 \times 45 \mathrm{~cm}^{2}$ yielding 2,025 $\mathrm{cm}^{2}$ of area sampled. The trap height was $50 \mathrm{~cm}$ with a round plastic container on top that had an opening in the middle. The insects entered the trap through that opening and fell into $1 \%$ formalin solution that covered the bottom of the plastic container. The sides of the pyramid were covered with green plastic or grey metal mesh with $1 \mathrm{~mm}$ mesh size (it was designed by Mladen Vajdić, Nenad Vajdić and Mladen Kučinić). This system ensured the entrapment of emerged insects and their conservation in the pyramidal trap container. The containers were emptied one or two times a month, and regularly at the end of the month. This type of emergence trap continued to be used in other studies in the Plitvice Lakes NP (e.g. Ivković et al,. 2013a, 2013b, 2015; Previšić et al., 2013; ŠEMničKi et al., 2011, 2012; Vilenica et al., 2017a, 2017b) as well as in other localities in Croatia (Krka National Park, Previšrć et al., 2017; Banovina region, Kučinıć et al., 2013; Szivék et al., 2017; spring Škodilovac in Slavonia, S. Žalac \& A. Delić unpublished data) and Bosnia and Herzegovina (spring Bistrica in Livno, M. Kučinić, S. Žalac unpublished data). 
a)

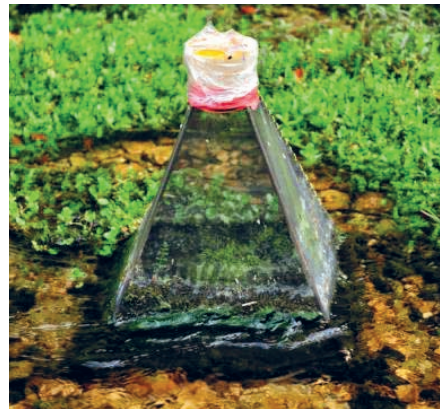

b)

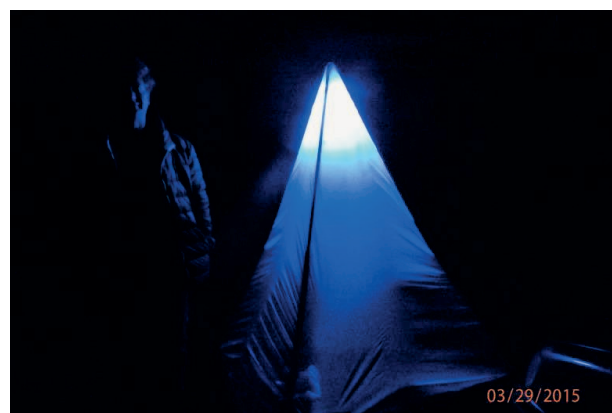

Fig. 8a-b. (a) Pyramid-type emergence trap fixed to the bottom of the stream (Plitvice Lakes NP) and (b) light-trap Kolansko Blato, island Pag (with dr. sc. Gordan Lukač).

\section{Localities of our investigations (Fig. 1) with longitudes, latitudes and altitudes:}

1. Spring of Bijela rijeka (SBR) (mountain spring of a rheocrene type, upper lotic habitat); pyramidtype emergence traps were placed in the central section and in close proximity to the left bank of the stream; collecting with light traps (Fig. 8b) was done on the left bank of the spring; the spring is located at the end of a valley surrounded by forest; E 15 $33^{\prime} 43^{\prime \prime}$, N $44^{\circ} 50^{\prime} 05^{\prime \prime}$, altitude $=720 \mathrm{~m}$;

2. Spring of Crna rijeka (SCR) (mountain spring of a rheocrene type, upper lotic habitat); pyramidtype emergence traps were placed in the central section and in close proximity to the left bank of the stream; collecting with light traps was done on the right bank of the spring; the spring is lo-

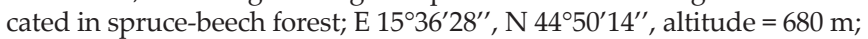

3. Bijela rijeka - middle part (BR) (upper lotic habitat $2.1 \mathrm{~km}$ from the spring); collecting with light traps was done on the left bank of the stream; the location is in the open area next to the asphalt motorway; the flow width is $1.8 \mathrm{~m}$; E $15^{\circ} 34^{\prime} 52^{\prime \prime}, \mathrm{N} 44^{\circ} 50^{\prime} 24^{\prime \prime}$, altitude $=691 \mathrm{~m}$;

4. Crna rijeka - middle part (CR) (upper lotic habitat $2.7 \mathrm{~km}$ from the spring); collecting with light traps was conducted on the right side of the river while pyramid-type emergence traps were placed in the same place but on the opposite side of the stream; located in the forest; the flow width is

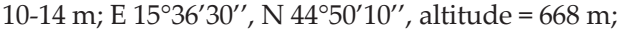

5. Stream Plitvica (SP) (lower lotic habitat); sampling site was placed on the bridge across the stream $30 \mathrm{~m}$ away from the waterfall Veliki slap; the locality is in the open area; the flow-width is $4-5 \mathrm{~m}$; E $15^{\circ} 36^{\prime} 27^{\prime \prime}$, N $44^{\circ} 54^{\prime} 08^{\prime \prime}$, altitude = $554 \mathrm{~m}$;

6. River Korana - upper part (KR); the locality for collection with light traps was placed in the village Korana, $50 \mathrm{~m}$ downstream of the bridge on the left side of the river; the locality is in a meadow next

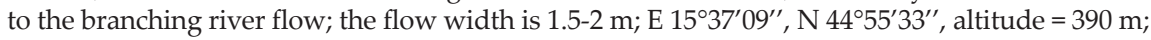

7. Prošćansko Lake (PL) (upper lake); the locality for collecting with light traps was placed $2.5 \mathrm{~km}$ from Labudovac tufa barrier on the right bank of the lake next to the asphalt motorway; locality is in open area; E 15 36 $09^{\prime \prime}, \mathrm{N} 44^{\circ} 51^{\prime} 33^{\prime \prime}$, altitude = $638 \mathrm{~m}$;

8. Galovac Lake (GL) (upper lake); locality for collecting with light traps was placed in the middle part of the right bank of the lake; located in the forest; E $15^{\circ} 36^{\prime} 25^{\prime \prime}, \mathrm{N} 44^{\circ} 52^{\prime} 26^{\prime \prime}$, altitude $=585 \mathrm{~m}$;

9. Kozjak Lake (KL) (upper lake); locality for collecting with light traps was placed on the right bank

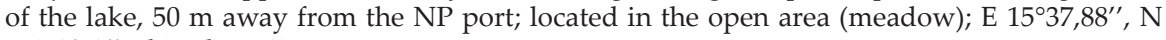
$44^{\circ} 52^{\prime} 49^{\prime \prime} ;$ altitude $=537 \mathrm{~m}$;

10. Tufa barrier Labudovac (TBL); (the barrier starts at the end of the Prošćansko Lake - upper lake); the pyramid-type emergence traps were placed in the middle part of the barrier while collecting with light traps was conducted on the right side of the tufa barrier; located partly in the forest; $\mathrm{E}$ $15^{\circ} 35^{\prime} 59^{\prime \prime}, \mathrm{N} 44^{\circ} 52^{\prime} 17^{\prime \prime}$, altitude $=630 \mathrm{~m}$;

11. Tufa barrier Kozjak/Milanovac (TBKM) (between Kozjak Lake (upper) and Milanovac Lake (lower); the pyramid-type emergence traps were placed on the right side of the barrier; collecting was done with light traps; the locality is partly covered with forest-brushwood vegetation; E $15^{\circ} 36^{\prime} 32^{\prime \prime}$, $\mathrm{N} 44^{\circ} 53^{\prime} 39^{\prime \prime}$, altitude $=544 \mathrm{~m}$; 
12. Tufa barrier Novakovića Brod (TBNB) (between Kaluđerovac Lake and Novakovića Brod Lake lower lakes); the pyramid-type emergence traps were placed on the right side of the tufa barrier; collecting with light traps was conducted on the right side of the tufa barrier; the locality is in the open area; $\mathrm{E} 15^{\circ} 36^{\prime} 38^{\prime \prime}, \mathrm{N} 44^{\circ} 50^{\prime} 07^{\prime \prime}$, altitude $=500 \mathrm{~m}$.

\section{Laboratory work and data analysis}

Females belonging to genera Glossosoma, Hydropsyche and Wormaldia could not be identified to the species level and therefore are listed as Glossosoma sp. (female), Hydropsyche sp. (female) and Wormaldia sp. (female). Females without males were recorded only for the family Hydropsychidae in the locality Crna rijeka - middle part. Therefore, this record was counted as one additional species for that locality. Since the exact species could not be identified this record was not considered at the level of fauna.

The Trichoptera checklist was based on data from our research conducted in the period from 1997 to 2007 (KuČinić, 2002; Kučinić \& Malicky, 2002; Kučinić et al., 2008; Previšić et al., 2007, 2010) and the data that was acquired in the following studies (Š̈EMničKI et al., 2011, 2012; Previšrć et al., 2013; Ivкоvić et al., 2013b). The record of Lype reducta Hagen in the tufa barrier Kozjak/Milanovac (Previšić et al., 2007) was not considered in the analysis due to the absence of specimens in the Faculty collection and the inability to confirm determination. The data about emergency period of Chaetopteryx fusca Brauer from the study of ŠEMNIČKI et al. (2011) in May and June are technical mistake in the paper and we do not use them in analyses of this study. The flight period of caddisflies in Plitvice Lakes NP was shown according to data in the Appendix and in studies: Kučinić (2002), Kučinić \& MaLicky (2002), Kučinić et al. (2008), ŠemničKi et al. (2011), Previšić et al. (2013) and Ivković et al. (2015). Data for specimens collected by pyramid-type emergence traps on 2.X.2000 and on 2.XI.2000 are in flight period analysis shown for September and October, respectively.

The species Wormaldia occipitalis Pictet will be subject of a separate study with morphological and molecular analysis. According to Neu in Croatia Wormaldia subterranea Radovanović is distributed, and not W. occipitalis Pictet (Neu, 2015). In this study we list this species as Wormaldia cf. occipitalis Pictet (Tabs. 1, 3, 10).

The comparison of caddisfly assemblages in different types of habitats was done using the Sørensen Index of Similarity (SøRENSEN, 1948). Caddisfly adults were determined according to the standard literature: Kumanski (1988) and Malicky (2004). Systematics follow Malicky (2004) and Morse (2017). The collected caddisfly specimens are deposited in the Croatian Natural History Museum in Zagreb and in the Department of Biology, Faculty of Science, University of Zagreb.

\section{RESULTS AND DISSCUSION}

\section{Historic overview of research on caddisflies in the Plitvice Lakes NP}

The first research on Trichoptera species in the area of the the Plitvice Lakes NP started in the 1950s. The pioneers of these studies were biologists from the Faculty of Science, University of Zagreb that conducted studies on the ecological characteristics of karstic stream biocenoses (MATONIČKIN, 1959; MatoničKin \& PAVLETić, 1961, 1967; MatOničKIn et al., 1971). The analysis of macrozoobenthos is very important in this kind of studies (HabDiJa 1989; HabDija et al., 2004) however the faunistic characteristics and biodiversity of many aquatic groups, including Trichoptera, are hampered by lack of taxonomic knowledge (KučInIĆ, 2002; WARINGER \& GRAF, 1997, 2011). In fact, for many Trichoptera genera, it is impossible to distinguish species at the larval stage because the morphological differences-characters have not yet been defined (WARINGER \& GRAF, 1997, 2011). In these early studies on the macrozoobenthos in the Plitvice Lakes about 40 Trichoptera taxa have been identified (MatoničKIn, 1959, 1987; Habdija, 1989; Habdija et al., 2004). A small number of species found in these limnological studies (e.g. Rhyacophila nubila Zetterstedt, Chaetopteryx villosa Fabricius, Diplectrona felix McLachlan) (MatoničKIn, 1987; HabdiJa, 1989) could not be detected in our study.

Up to that time only about 65 Trichoptera species were known for Croatian fauna (e.g. KLAPÁLeK, 1906; LANGHoffer, 1915; MarinKović-Gospodnetić, 1971, 1979; KRušNiK, 1987; KučInIĆ \& Ilić, 1993); and about 40 species for Plitvice Lakes, mainly based on identification of larvae specimens (e.g. MatoničKin, 1987; MatoničKIN et al., 1971; HABDIJA, 1989). The first complex collection of Trichoptera adults in Croatia was conducted by Prof. Mara Marinković-Gospodnetić from the University of Sarajevo in 1970s, as a part of the research of caddisfly species in karstic springs in Dinaric region 
(MARinković-Gospodnetić, 1971, 1979). This study included four river springs: river Kostelka, river Gacka and two streams in the Plitvice Lakes area, Plitvica and Crna Rijeka, respectively. During this research 17 Trichoptera species were determined and 6 of them were identified in the area of the Plitvice Lakes (MARinković-Gospodnetić, 1971, 1979). The most interesting result was a new species from family Limnephilidae in the area of the Plitvice Lakes, Drusus croaticus Marinković-Gospodnetić (Marinković-Gospodnetić, 1971). The larval stage of this species was described for the first time using specimens from the area of the Plitvice Lakes NP (Kučinić et al., 2008).

Systematic studies of the biodiversity, distribution, taxonomy and ecological features of caddisflies in the Plitvice Lakes started 20 years ago (Appendix; Kučinić, 2002; KučInIć \& Malicky, 2002; Previšıć et al., 2007, 2010). In that period scientists from the Croatian Natural History Museum in Zagreb started collecting adult caddisflies and the first doctoral thesis in that scientific area was written (KučINIĆ, 2002) where 75 caddisfly species were determined for the Plitvice Lakes NP area (KučinIĆ, 2002; KučInIĆ \& MaLicky, 2002; Kučinić et al., 2008) (Tab. 1). In this study the most interesting data was the newly described subspecies, Rhyacophila dorsalis plitvicensis Kučinić \& Malicky (KučınIć \& MaLICKY, 2002). The only known distribution area of $R$. d. plitvicensis Kučinić \& Malicky is located in the Plitvice Lakes NP, with the exception of the area of the river Cetina in Mediterranean part of Croatia (VučKović, 2011). In the northern and western parts of Croatia another subspecies of $R$. dorsalis is distributed, Rhyacop-

Tab. 1. Collected caddisflies using light traps in 1997 in different types of habitats and locations in the Plitvice Lakes NP: 1 - spring of Bijela rijeka, 2 - spring of Crna rijeka; 3 - stream Bijela Rijeka - middle part, 4 - stream Crna Rijeka - middle part, 5 - stream Plitvica - lower part, 6 - River Korana - upper part; 7 - Prošćansko Lake, 8 - Galovac Lake, 9 - Kozjak Lake, 10 - tufa barrier Labudovac, 11 - tufa barrier Kozjak/Milanovac, 12 - tufa barrier Novakovića Brod; tufa bar.= tufa barrier, 妏 - females.

\begin{tabular}{|c|c|c|c|c|}
\hline \multirow{2}{*}{ Species } & Springs & Streams & Lakes & \multirow{2}{*}{$\begin{array}{l}\text { Tufa bar. } \\
1011 \quad 12\end{array}$} \\
\hline & 12 & $\begin{array}{llll}3 & 4 & 5 & 6\end{array}$ & $\begin{array}{lll}7 & 8 & 9\end{array}$ & \\
\hline \multicolumn{5}{|l|}{ Familiy Rhyacophilidae } \\
\hline Rhyacophila aurata Brauer & & $\bullet \bullet \bullet \bullet$ & - & $\bullet \bullet \bullet$ \\
\hline Rh. dorsalis plitvicensis Kučinić \& Malicky & & - & $\bullet \bullet$ & $\bullet \bullet \bullet$ \\
\hline Rhyacophila fasciata Hagen & $\bullet \bullet$ & $\bullet \bullet \bullet$ & & $\bullet$ \\
\hline Rhyacophila schmididinarica Ur., Kr.\& Mal. & $\bullet$ & & & \\
\hline Rhyacophila tristis Pictet & $\bullet$ & $\bullet \bullet \bullet \bullet$ & - & $\bullet$ \\
\hline \multicolumn{5}{|l|}{ Family Glossosomatidae } \\
\hline Synagapetus krawanayi Ulmer & - & - $\bullet$ & & \\
\hline Glossosoma bifidum McLachlan & $\bullet$ & & & \\
\hline Glossosoma discophorum Klapálek & $\bullet \bullet$ & $\bullet \bullet$ & & \\
\hline Glossosoma sp. (females) & 必 & 宗 & & \\
\hline \multicolumn{5}{|l|}{ Family Philipotamidae } \\
\hline Philopotamus montanus Donovan & - & $\bullet$ & & $\bullet$ \\
\hline Philopotamus variegates Scopoli & & & & $\bullet$ \\
\hline Wormaldia cf. occipitalis Pictet & & $\bullet$ & & $\bullet$ \\
\hline Wormaldia subnigra McLachlan & $\bullet$ & - & $\bullet \bullet$ & $\bullet \bullet \bullet$ \\
\hline Wormaldia sp. (female) & 嫁 & 如 & ; & 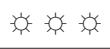 \\
\hline \multicolumn{5}{|l|}{ Family Polycentropodidae } \\
\hline Cyrnus trimaculatus Curtis & $\bullet$ & - & $\bullet \bullet$ & \\
\hline Neureclipsis bimaculata Linnaeus, 1758 & & & & $\bullet \bullet$ \\
\hline Plectrocnemia brevis McLachlan & $\bullet \bullet$ & & $\bullet$ & \\
\hline
\end{tabular}




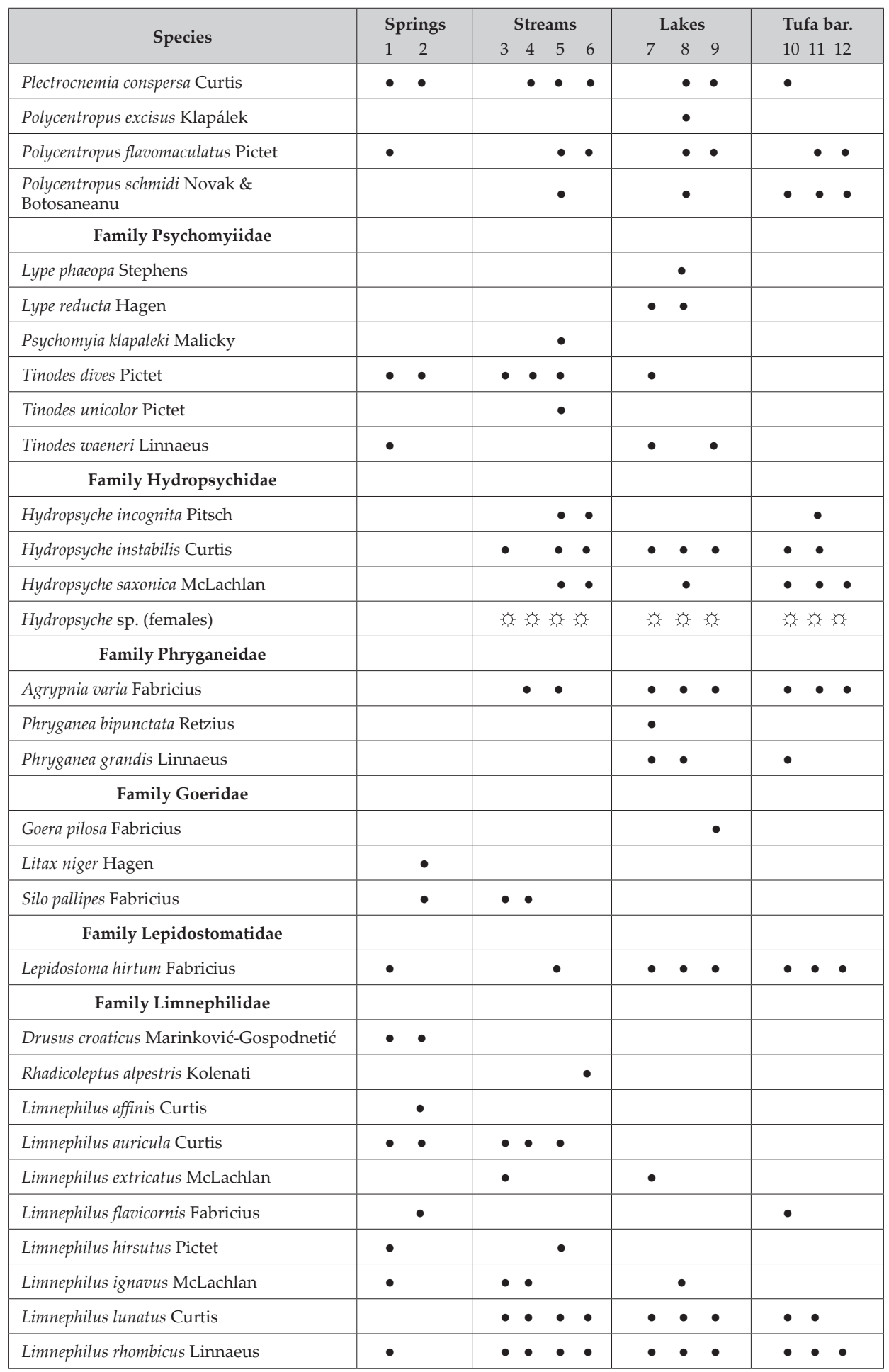




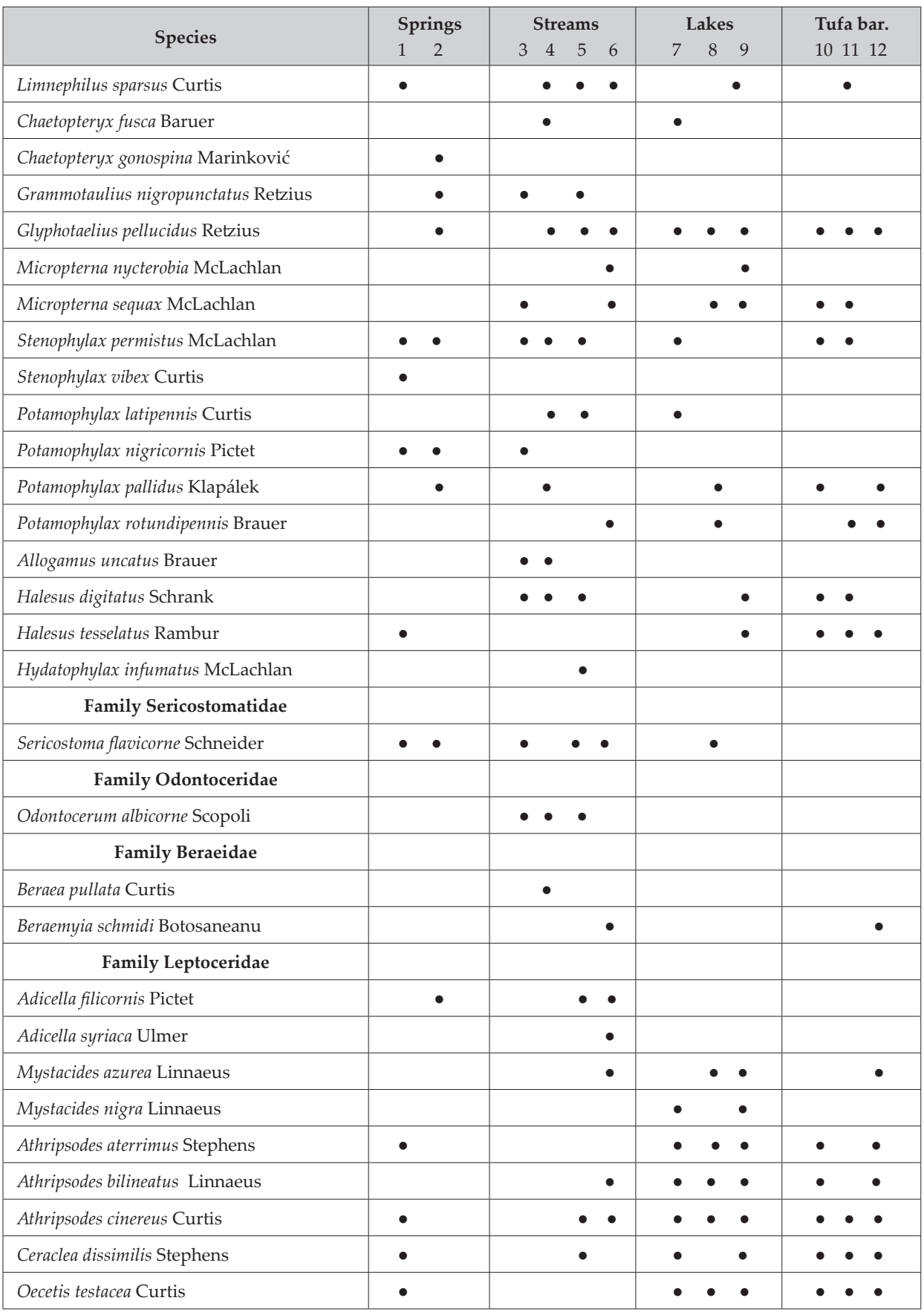


hila dorsalis permislis McLachlan (MaLicKy, 2002c, 2004). In our investigation we did not find any contact zone between these two subspecies (M. KučInIć, unpublished data).

The Plitvice Lakes NP is also locus typicus for D. croaticus Marinković-Gospodnetić described by specimens collected in the springs of Bijela Rijeka and Plitvica (Marinković-Gospodnetić, 1971). This species was later found in more than 20 localities across Croatia and has been analysed in phylogenetic, phylogeographic and taxonomic studies (Kučinić et al., 2008; Previšrć et al., 2009, 2014). Some aspects of this species' life cycle with description of its last larval stage were analysed at the Plitvice Lakes (Kučinıć, 2002; Kučınić et al., 2008).

The investigation of emergence features of aquatic insects in the Plitvice Lakes using pyramid-type emergence traps started at the end of the $20^{\text {th }}$ century. In the period from 2000 to 2001, 16 pyramid emergence traps were placed in different types of habitats in the National Park. In this investigation 37 caddisflies species were identified, two of which, Micropterna lateralis Stephens and Notidobia ciliaris Linnaeus were new to this area (Kučinić, 2002; Previšić et al., 2007) (Tab. 1).

During 2007 a collecting expedition was organized in Croatia with the aim of gaining better knowledge on aquatic insects species. The expedition team comprised not only Croatian scientists from the Faculty of Science (Zagreb) but also colleagues from Slovenia, Bogdan Horvat and Ignac Sivec, and colleagues from Austria, Wolfram Graf and Professor Hans Malicky. During that research, Professor Hans Malicky and Wolfram Graf found the following 4 unknown Trichoptera species for the area of National Park and also for Croatia: Crunoecia kempnyi Morton, Ernodes articularis Pictet, Ernodes vicinus McLachlan and Oecetis lacustris Pictet, 1834 (Tab. 3). With these data and studies conducted during 1997, 2000 and 2001 (Kučinić, 2002; Previšić et al., 2007; Kučinić et al., 2008) the number of species in the Plitvice Lakes NP was estimated to be 81 taxa (Previšić et al., 2010). It was the first checklist of Trichoptera for the area of the National Park published in the Austrian journal Denisia (Previšić et al., 2010).

Study of aquatic insects of the Plitvice Lakes NP using pyramid-type emergence traps started in 2007 resulting in a lot of very interesting data (e.g. Ivкović et al., 2013a, 2013b, 2015; VILENICA et al., 2017a, 2017b). Seven more caddisfly species, previously unknown for the area, were found in those investigations - Hydroptila cognata Mosely, Hydroptila occulta Eaton, Hydroptila rheni Ris, Ecnomus tenellus Rambur, Apatania muliebris McLachlan, Potamophylax luctuosus Piller \& Mitterpacher and Ceraclea annulicornis Stephens, 1836 (ŠEmničKı et al., 2011, 2012; PrevišIć et al., 2013) (Tab. 3). The species Beraeodes minutus Linnaeus was registered as new in papers (ŠEMNIČKI et al., 2011, 2012) but was also reported before, as larval stage by HabDIJA (1989).

According to the present data on Trichoptera species, the fauna of the Plitvice Lakes NP reaches 89 species from 46 genera and 16 families (Tabs. 3-4). Thus, it can be concluded that regarding caddisflies the Plitvice Lakes NP is the best-studied area in Croatia and also among the best researched areas in Europe. Currently there are several studies being conducted in the Plitvice Lakes NP that include caddisflies. The ongoing analysis of specimens collected by window-traps in 1999 and pyramid-type emergence traps in 2007 are expected to provide new knowledge of the caddisfly fauna of this area.

\section{Faunal data and distribution of caddisflies in the Plitvice Lakes NP in studies from 1997 to 2001}

During 1997, 75 species from 39 genera and 14 families were determined from approximately 4,150 Trichoptera specimens collected using light traps in the area of the Plitvice Lakes NP (Tabs. 1-2). The greatest number of caddisfly species in Croatian fauna was determined for the first time in this study (Kučinić, 2002). All species found in the Plitvice Lakes NP were determined by male adults except for two species, Beraea pullata Curtis and Stenophylax vibex Curtis, which were determined using females. Future studies will confirm the presence of those species in the Plitvice Lakes NP with findings of male specimens.

During 2000 and 2001, 37 species from 25 genera and 11 families were determined from 1,350 caddisfly specimens collected using pyramid-type emergence traps (KučInIć, 2002; Previšić et al., 2007). Collections with pyramid-type emergence traps yielded two species, M. lateralis McLachlan and N. ciliaris Linnaeus which were not collected using light traps. In total 77 species were found during this research period (Kučinić, 2002; Previšić et al., 2007). 
In the period from 1997 to 2001 the following species were faunistically most interesting: Rhyacophila schmididinarica Urbanič, Krušnik \& Malicky, Glossosoma bifidum Mclachlan Glossosoma discophorum Klapálek, Polycentropus excisus Klapálek, Polycentropus schmidi Novak \& Botosaneanu, Tinodes waeneri Linnaeus, Psychomyia klapaleki Malicky, Hydropsyche incognita Pitsch, D. croaticus MarinkovićGospodnetić, Limnephilus extricatus McLachlan, Limnephilus ignavus McLachlan, Chaetopteryx gonospina Marinković-Gospodnetić, Potamophylax nigricornis Pictet, Potamophylax rotundipennis Brauer, Allogamus uncatus, Brauer, Halesus tessellatus Rambus, Hydatophylax infumatus McLachlan, Beraeamyia schmidi Botosaneanu, Adicella filicornis Pictet and Oecetis testacea Curtis (Tab. 1). Many of these species were found in Croatia for the first time and a significant number of them was later found in other parts of Croatia (e.g. Graf et al., 2008a; WAringer et al., 2009; Kučinić et al., 2011; Cerjanec, 2012; Previšić et al., 2012, 2014). However, for some species, e.g. P. excisus Klapálek, L. extricates McLachlan, L. ignavus McLachlan, H. infumatus McLachlan, B. schmidi Botosaneanu and A. filicornis Pictet, the Plitvice Lakes NP is the only known locality in Croatia, which additionaly shows the specificity of the Plitvice Lakes hydrological system.

Tab. 2. Families, number of species and distribution according to investigation in 1997 (light traps): 1 - spring of Bijela rijeka, 2 - spring of Crna rijeka, 3 - Bijela rijeka - middle part, 4 - Crna rijeka - middle part, 5 - stream Plitvica - lower part, 6 - river Korana - upper part, 7 - Prošćansko Lake, 8 - Galovac Lake, 9 - Kozjak Lake, 10 - Tufa barrier Labudovac, 11 - Tufa barier Kozjak/Milanovac, 12 - Tufa barrier Novakovića Brod.

\begin{tabular}{|l|c|c|c|c|c|c|c|c|c|c|c|c|}
\hline Families & $\mathbf{1}$ & $\mathbf{2}$ & $\mathbf{3}$ & $\mathbf{4}$ & $\mathbf{5}$ & $\mathbf{6}$ & $\mathbf{7}$ & $\mathbf{8}$ & $\mathbf{9}$ & $\mathbf{1 0}$ & $\mathbf{1 1}$ & $\mathbf{1 2}$ \\
\hline Rhyacophilidae & 1 & 3 & 3 & 3 & 3 & 3 & 1 & 3 & - & 3 & 2 & 3 \\
\hline Glossostomatidae & 1 & 3 & 2 & 2 & - & - & - & - & - & - & - & - \\
\hline Philopotamidae & 1 & 1 & 1 & 1 & - & 2 & 1 & 1 & - & 1 & 1 & 4 \\
\hline Polycentropodidae & 4 & 2 & - & 1 & 3 & 3 & 1 & 6 & 2 & 3 & 3 & 2 \\
\hline Psychomiidae & 2 & 1 & 1 & 1 & 3 & - & 3 & 2 & 1 & - & - & - \\
\hline Hydropsychiidae & - & - & 1 & 1 & 3 & 3 & 1 & 2 & 1 & 2 & 3 & 1 \\
\hline Phryganeidae & - & - & - & 1 & 1 & - & 3 & 2 & 1 & 2 & 1 & 1 \\
\hline Goeridae & - & 2 & 1 & 1 & - & - & - & - & 1 & - & - & - \\
\hline Lepidostomatidae & 1 & - & - & - & 1 & - & 1 & 1 & 1 & 1 & 1 & 1 \\
\hline Limnephiliade & 10 & 10 & 11 & 12 & 11 & 8 & 7 & 7 & 8 & 9 & 9 & 5 \\
\hline Sericostomatidae & 1 & 1 & 1 & - & 1 & 1 & - & 1 & - & - & - & - \\
\hline Odontoceridae & - & - & 1 & 1 & 1 & - & - & - & - & - & - & - \\
\hline Bearidae & - & - & - & 1 & - & 1 & - & - & - & - & - & 1 \\
\hline Leptoceridae & 4 & 1 & - & - & 3 & 5 & 6 & 5 & 7 & 5 & 3 & 6 \\
\hline Number of species & $\mathbf{2 5}$ & $\mathbf{2 4}$ & $\mathbf{2 2}$ & $\mathbf{2 5}$ & $\mathbf{3 0}$ & $\mathbf{2 6}$ & $\mathbf{2 4}$ & $\mathbf{3 0}$ & $\mathbf{2 2}$ & $\mathbf{2 6}$ & $\mathbf{2 3}$ & $\mathbf{2 4}$ \\
\hline
\end{tabular}

The number of species collected in each site in the Plitvice Lakes NP by light traps varied from 22 species collected at the stream Bijela Rijeka - middle part and the Kozjak/Milanovac tufa barrier to 30 species found at the stream Plitvica - lower part and the Galovac Lake (Tab. 2). Using emergencetype pyramid traps during a two-year study (2000-2001), the lowest species number was collected at the Bijela Rijeka spring (9) and the highest (22 species) was found at the Labudovac tufa barrier (Kučinić, 2002; Previšić et al., 2007). During later studies, the number of species collected by pyramidtype emergence traps increased (ŠEMničKi et al., 2011, 2012; Previšić et al., 2013).

\section{Habitats and biodiversity of the caddisfly fauna in the Plitvice Lakes NP}

According to the faunistical results using light traps during 1997, the following number of caddisfly species were determined: in springs 39, in streams 53, in lakes 44 and at tufa barriers 36 (Tab. 1). The analysis of the similarity in faunal composition of species collected by light traps showed the greatest similarity between the ecologically mostly similar sites (Tab. 6). This was not expected because sampling by light traps attracts not only insects present in the actual habitat where the colle- 
Tab. 3. Second checklist of caddisflies in the Plitvice Lakes NP with distribution data on different types of habitats and locations: 1 - spring of Bijela rijeka, 2 - spring of Crna rijeka; 3 - stream Bijela Rijeka middle part, 4 - stream Crna Rijeka - middle part, 5 - stream Plitvica - lower part, 6 - River Korana upper part; 7 - Prošćansko Lake, 8 - Galovac Lake, 9 - Kozjak Lake, 10 - tufa barrier: Labudovac, 11 - tufa barrier: Kozjak/Milanovac, 12 - tufa barrier: Novakovića Brod; Tufa bar.= tufa barriers, 呟 - females.

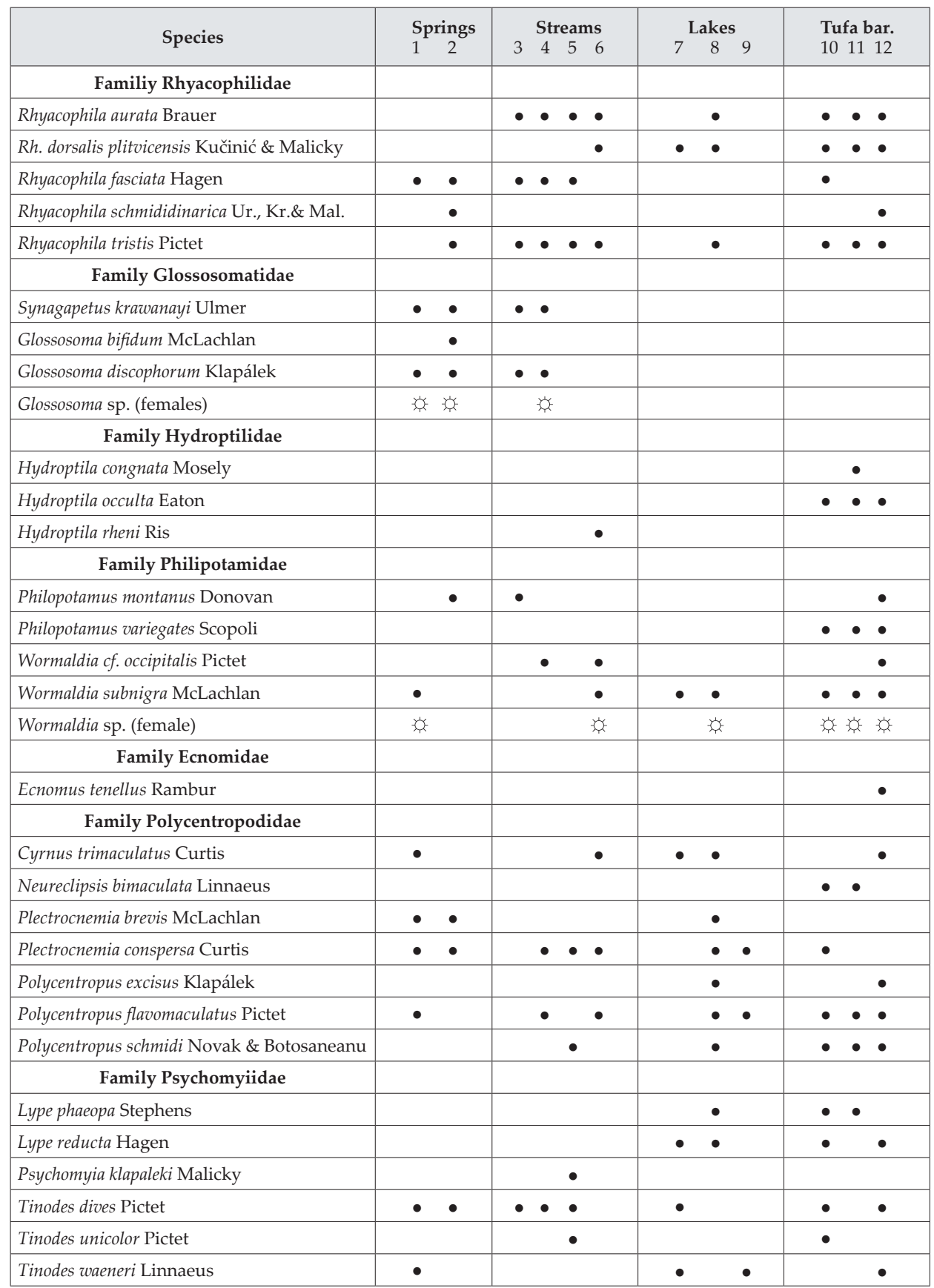




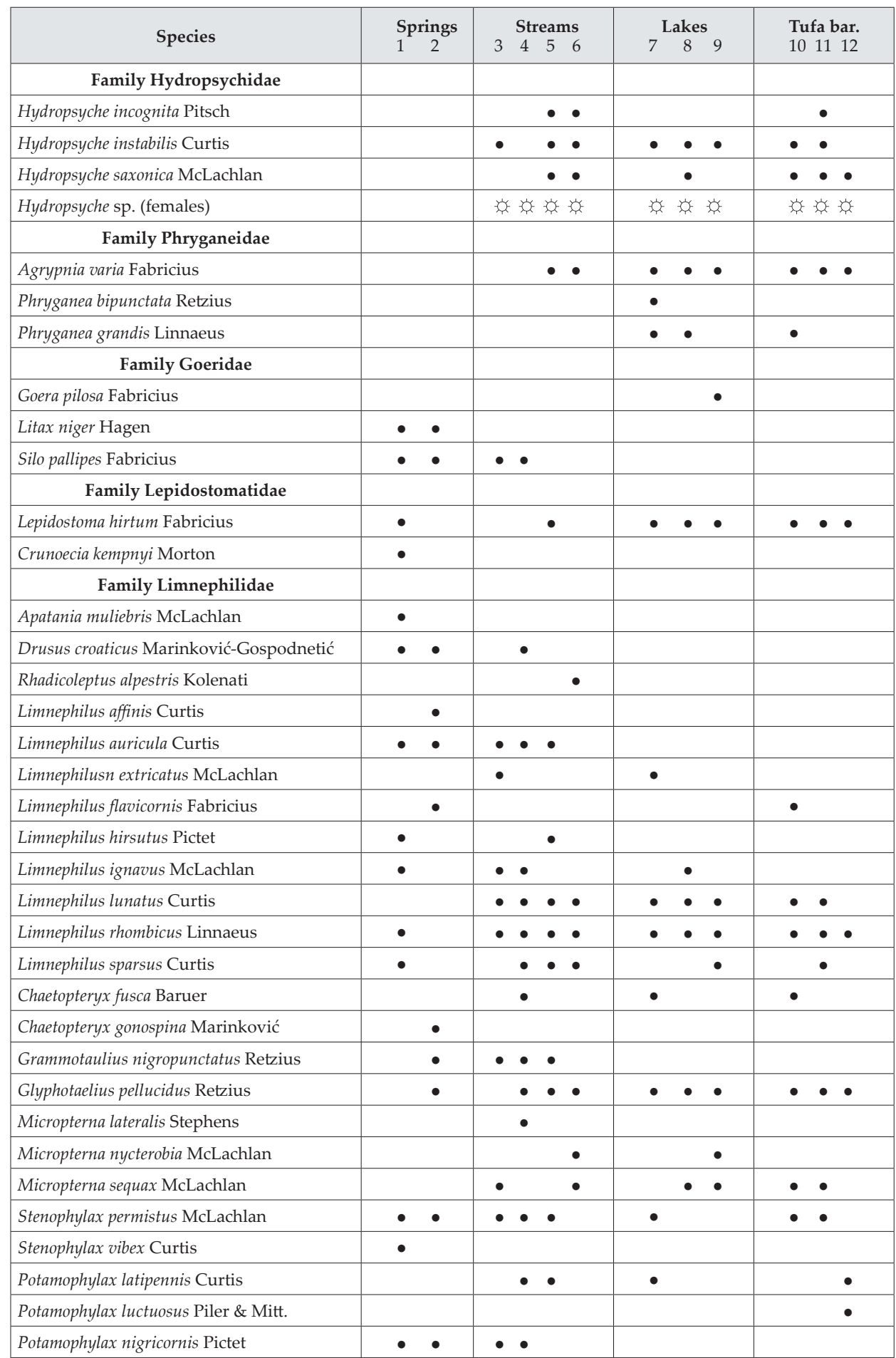




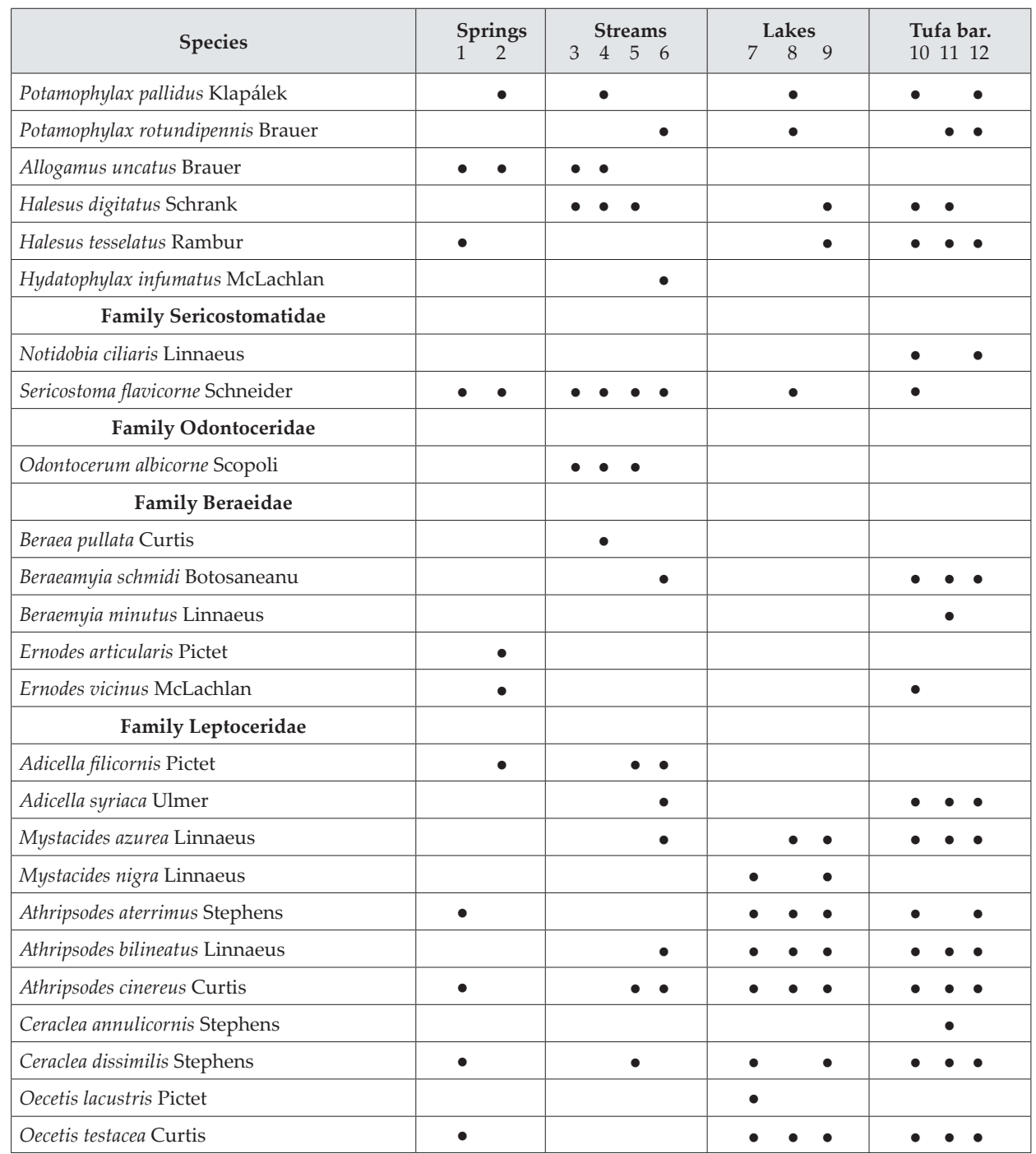

ction is being done, but also specimens from more distant habitats (Kučinıć, 2002). These data suggests that this method also shows the composition of fauna in certain site. The lowest Sørensen's similarity index values (Sørensen, 1948) were recorded between spring of Crna rijeka and tufa barrier Kozjak/Milanovac (8.5\%), and spring of Crna rijeka and the Kozjak Lake (8.7\%), while it was the highest between tufa barrier Labudovac and tufa barrier Kozjak/Milanovac (77.6\%) (Tab. 6).

If the overall results for the caddisfly fauna of the Plitvice lakes NP are considered as 89 species (Tabs 3-4) (Kučinić, 2002; Kučinić \& MaLicky, 2002; Previšić et al., 2007, 2010, 2013; Kučinić et al., 2008; Ivкоvić et al., 2013b) it can be perceived that almost all types of habitats (springs, streams, lakes and tufa barriers) are home to $49-63 \%$ of the total species number recorded in the NP area, i.e. from 44 for the springs to 56 species for the streams and tufa barriers (Tab. 8). The total number of species recorded in the springs varies from 27 to 31 , from 22 to 30 in the streams, from 22 to 30 in lakes, and in tufa barriers from 34 to 41, where the highest number of species has been recorded (Tab. 5). The lowest and the highest species number were registered in the middle reach of the Bijela rijeka stream and Kozjak Lake (22 species), and in the tufa barrier Labudovac (41 species), respectively (Tabs 3, 5). 
Tab. 4. Families and number of species established in the Plitvice Lakes NP, 1, 2, $3=$ number of species (KuČinić, 2002; Ivković et al., 2013c; Previšić et al., 2007, 2013; ŠEMničKi et al., 2011, 2012).

\begin{tabular}{|l|c|c|c|c|c|}
\hline Families & $\mathbf{1}$ & Families & $\mathbf{2}$ & Families & $\mathbf{3}$ \\
\hline Rhyacophilidae & 5 & Psychomiidae & 6 & Limnephilidae & 30 \\
\hline Glossostomatidae & 3 & Hydropsychidae & 3 & Sericostomatidae & 2 \\
\hline Hydroptiliidae & 3 & Phryganeidae & 3 & Odontoceridae & 1 \\
\hline Philopotamidae & 4 & Goeridae & 3 & Beraeidae & 5 \\
\hline Polycentropodidae & 7 & Lepidostomaiidae & 2 & Leptoceridae & 11 \\
\hline Ecnomidae & 1 & - & & - & \\
\hline
\end{tabular}

Sørensen's similarity index (Sørensen, 1948) showed that the species assemblages at the tufa barriers and in the lakes were the most similar $(73.2 \%)$ and the highest differences exist between springs and lakes (47.1\%) and springs and tufa barriers (48\%) (Tab. 9). These results were expected to some extent because Trichoptera assemblages at tufa barriers also include species from surrounding habitats, e.g. streams and lakes (ŠmničKi et al., 2012). The specific geology, geomorphology, physico-chemical properties, hydrology and other organisms, specifically moss, constitute a whole spectrum of microhabitats and microspaces in one dynamic system. This system is rich in different fractions of particulate organic matter (seston, plankton biomass) that forms a specific trophic structure (Habdija et al., 2004; Miliša et al., 2006, 2014; Š POLJAR et al., 2007a, 2007b), therefore enabling specificity and great biodiversity of different groups of organisms living on tufa barriers, including Trichoptera (e.g. Wood et al., 2000; HabDija et al., 2004; WAGNER \& SCHMidT, 2004; Matić et al., 2016). These characteristics of tufa barriers make them equal to streams and smaller rivers which usually have the greatest biodiversity of Trichoptera (WALLAcE et al., 1990). This is in line with the results of our study (Tab. 3, 9).

The composition and structure of the caddisfly fauna at the rheocrene-type springs of the Bijela rijeka and Crna rijeka streams are particularly interesting (Tabs. 1,3). Similarity of caddisflies fauna between these two springs based on data collected with light traps in 1997 was 40.8\% according to the Sørensen similarity index (Tab. 6). However, when all available data from these two sites were included (Appendix, Kučinić, 2002; Previšrć et al., 2007, 2010, 2013; Ivković et al., 2013b) a higher value (48.3\%) was obtained (Tab. 7). Those two springs will be a part of a separate study using different sampling methods (pyramidtype emergence traps and light traps) but results of this study show a much higher degree of difference than could have been expected. These results are most probably conditioned by their locality and basic features. Namely, the Crna rijeka spring is situated in the forest (closed canopy spring) while this is not the case with the spring of Bijela rijeka (open canopy spring) which leads to a completely different daylight regime (illuminance) and differences in composition and structure of dry, fallen leaves in those sites. Although they are of rheocrene-type, they differ considerably in their hydrological (water velocity is higher in the Crna rijeka spring) (Ivković et al., 2015) and geomorphological (the spring of Bijela rijeka is in the end of a valley while the spring of Crna rijeka is on a hill side in the forest) characteristics. All the stated facts condition their differences which are reflected in the differences in composition and structure of the macroinvertebrate fauna (Ivкović et al., 2015; Matić et al., 2016; Bednar et al., 2017) including Trichoptera (Kučinić, 2002; Previšić et al., 2007). Significant differences in the fauna of those two springs have been determined in other studies conducted on other aquatic insect groups (Ivкоvіс́ et al., 2015) and they are most probably defined by the aforementioned conditions. Springs are identified as hotspots of biodiversity in numerous studies (e.g. BARQuin \& DeATH, 2006; Bednar et al., 2017), but our results show that in the Plitvice Lakes NP, streams, lakes and tufa barriers have greater biodiversity in the case of caddisflies (Tabs. 3, 8).

Specificities and properties that condition the composition and structure of the fauna are highlighted by the following species: eight species were collected exclusively in the springs (G. bifidum McLachlan, Litax niger Hagen, C. kempenyi Morton, A. muliebris McLachlan, Limnephilus affinis Curtis, C. gonospina Marinković-Gospodnetić, Stenophylax vibex Curtis, E. articularis Pictet), 7 species only in the streams (H. rheni Ris, P. klapaleki Malicky, Rhadiocoleptus alpestris Kolenati, M. lateralis Stephens, H. infumatus McLachlan, Odontocerum albicorne Scopoli, Mystacides nigra Linnaeus, B. pullata Curtis), 4 only in the lakes (Phryganea bipunctata Retzius, Goera pilosa Fabricius, Oecetis lacustris Pictet) and 7 species only at the tufa barriers (H. cognata Mosley, H. occulta Eaton, Philopotamus variegatus, Donovan, E. tenellus Rambur, Neureclipsis bimaculata Linnaeus, P. luctuosus Piller \& Mitterpacher, B. minutus Linnaeus, Ceraclea annulicornis 
Tab. 5. Families, number of species and distribution of caddisflies in the Plitvice Lakes NP: 1 - spring of Bijela rijeka, 2 - spring of Crna rijeka, 3 - Bijela rijeka - middle part, 4 - Crna rijeka - middle part, 5 - stream Plitvica - lower part, 6 - river Korana - upper part, 7 - Prošćansko Lake, 8 - Galovac Lake 9 - Kozjak Lake, 10 - tufa barrier Labudovac, 11 - tufa barrier Kozjak/Milanovac, 12 - tufa barrier Novakovića Brod.

\begin{tabular}{|l|c|c|c|c|c|c|c|c|c|c|c|c|}
\hline Families & $\mathbf{1}$ & $\mathbf{2}$ & $\mathbf{3}$ & $\mathbf{4}$ & $\mathbf{5}$ & $\mathbf{6}$ & $\mathbf{7}$ & $\mathbf{8}$ & $\mathbf{9}$ & $\mathbf{1 0}$ & $\mathbf{1 1}$ & $\mathbf{1 2}$ \\
\hline Rhyacophilidae & 1 & 3 & 3 & 3 & 3 & 3 & 1 & 3 & - & 4 & 3 & 4 \\
\hline Glossostomatidae & 2 & 3 & 2 & 2 & - & - & - & - & - & - & - & - \\
\hline Hydroptilidae & - & - & - & - & - & 1 & - & - & - & 1 & 2 & 1 \\
\hline Philopotamidae & 1 & 1 & 1 & 1 & - & 2 & 1 & 1 & - & 2 & 2 & 4 \\
\hline Ecnomidae & - & - & - & - & - & - & - & - & - & - & - & 1 \\
\hline Polycentropodidae & 4 & 2 & - & 1 & 3 & 3 & 1 & 6 & 2 & 4 & 3 & 4 \\
\hline Psychomyiidae & 2 & 1 & 1 & 1 & 3 & - & 3 & 2 & 1 & 4 & 1 & 3 \\
\hline Hydropsychiidae & - & - & 1 & 1 & 3 & 3 & 1 & 2 & 1 & 2 & 3 & 1 \\
\hline Phryganeidae & - & - & - & 1 & 1 & - & 3 & 2 & 1 & 2 & 1 & 1 \\
\hline Goeridae & 2 & 2 & 1 & 1 & - & - & - & - & 1 & - & - & - \\
\hline Lepidostomatidae & 2 & - & - & - & 1 & - & 1 & 1 & 1 & 1 & 1 & 1 \\
\hline Limnephiliade & 12 & 11 & 11 & 16 & 11 & 8 & 7 & 7 & 8 & 10 & 9 & 7 \\
\hline Sericostomatidae & 1 & 1 & 1 & 1 & 1 & 1 & - & 1 & - & 2 & - & 1 \\
\hline Odontoceridae & - & - & 1 & 1 & 1 & - & - & - & - & - & - & - \\
\hline Bearidae & - & 2 & - & 1 & - & 1 & - & - & - & 2 & 2 & 1 \\
\hline Leptoceridae & 4 & 1 & - & - & 3 & 5 & 7 & 5 & 7 & 7 & 7 & 7 \\
\hline Number of species & $\mathbf{3 1}$ & $\mathbf{2 7}$ & $\mathbf{2 2}$ & $\mathbf{3 0}$ & $\mathbf{3 0}$ & $\mathbf{2 7}$ & $\mathbf{2 5}$ & $\mathbf{3 0}$ & $\mathbf{2 2}$ & $\mathbf{4 1}$ & $\mathbf{3 4}$ & $\mathbf{3 6}$ \\
\hline
\end{tabular}

Stephens) (Tab. 3). According to these data 27 species (30.3\%) were determined only in one type of habitat (springs, streams, lakes or tufa barriers).

The results of many studies suggest that some species have specific adaptations and show habitat specific distributions (e.g. JoHnson et al., 2004; BRоOкs et al., 2005; Graf et al., 2008b) which is in line with our observations. For example, family Odontoceridae with one species in the Plitvice Lakes NP, O. albicorne Scopoli has ecological adaptations to streams and rivers (Tabs 1-3, 5). While D. croaticus Marinković-Gospodnetić and all species from subfamily Drusinae (family Limnephilidae) have adaptations to springs and the crenal parts of mountain streams (Kučinıć et al., 2008, 2016; Previšrć et al., 2014; ViteceK et al., 2015, 2017; WARINGER et al., 2015). Additionally, species from the family Glossostomatidae were restricted to the same aquatic habitats (crenal part of streams) while, for instance, Tinodes unicolor Pictet is a specialist at tufa barriers (Edington \& Hildrew, 1995). Chaetopteryx bucari Kučinić, Szivák \& Delić and many other species from the genus Chaetopteryx (including C. fusca Brauer and C. gonospina Marinković-Gospodnetić found at the Plitvice Lakes) have adaptations to small streams and springs (Kučinıć et al., 2013; SzIvÁK et al., 2017) while E. tenellus Rambur is a well known specialist of large rivers and lakes, like most species of family Hydroptilidae and Limnephilidae, for instance (НіскіN, 1967; Graf et al., 2008b). Ecological speciation (NosiL, 2012) is a very important process for speciation, evolution and biodiversity of life on Earth, including also freshwater organisms (PAuls et al., 2008).

All the previously mentioned results indicate that micro-habitat diversity (springs, streams, 16 lakes, tufa barriers) and water quality have a dominant influence on the faunal biodiversity of a certain area (Waringer, 1996; Wiberg Larsen et al., 2000; Kučinić, 2002; Vilenica et al., 2017a, 2017b). These characteristics, which cannot be found in any other area in Croatia, make the Plitvice Lakes NP very specific area, resulting with very high caddisfly biodiversity observed in our studies.

During all these investigations none of the above species was recorded at all 12 localities (Tab. 1, 3). The most frequently found species were Limnephilus rhombicus Linnaeus which was found at 11 localities and Glyphotaelis pellucidus Retzius found at 10 localities (Tab 3). There were 21 species found at 
Tab. 6. Sørensen index of similarity beetwen different locations in the Plitvice Lakes NP in investigation 1997 (lamp traps): 1 - spring of Bijela rijeka, 2 - spring of Crna rijeka; 3 - stream Bijela Rijeka - middle part, 4 - stream Crna Rijeka - middle part, 5 - stream Plitvica - lower part, 6 - River Korana - upper part; 7 - Prošćansko Lake, 8 - Galovac Lake, 9 - Kozjak Lake, 10 - tufa barrier Labudovac, 11 - tufa barrier Kozjak/Milanovac, 12 - tufa barrier Novakovića Brod.

\begin{tabular}{|c|c|c|c|c|c|c|c|c|c|c|c|c|}
\hline Sites & 1 & 2 & 3 & 4 & 5 & 6 & 7 & 8 & 9 & 10 & 11 & 12 \\
\hline 1 & & $40.8 \%$ & $38.3 \%$ & $36.7 \%$ & $47.3 \%$ & $29.1 \%$ & $44.9 \%$ & $43.6 \%$ & $46.8 \%$ & $43.1 \%$ & $41.7 \%$ & $36.7 \%$ \\
\hline 2 & $40.8 \%$ & & $52.1 \%$ & $44.9 \%$ & $37.0 \%$ & $20.0 \%$ & $12.5 \%$ & $21.8 \%$ & $8.7 \%$ & $24.0 \%$ & $8.5 \%$ & $16.7 \%$ \\
\hline 3 & $38.3 \%$ & $52.1 \%$ & & $63.8 \%$ & $50.0 \%$ & $29.2 \%$ & $26.1 \%$ & $30.8 \%$ & $22.7 \%$ & $33.3 \%$ & $31.1 \%$ & $17.4 \%$ \\
\hline 4 & $36.7 \%$ & $44.9 \%$ & $63.8 \%$ & & $54.5 \%$ & $31.4 \%$ & $32.7 \%$ & $32.7 \%$ & $29.8 \%$ & $39.2 \%$ & $33.3 \%$ & $28.6 \%$ \\
\hline 5 & $47.3 \%$ & $37.0 \%$ & $50.0 \%$ & $54.5 \%$ & & $50.0 \%$ & $40.7 \%$ & $46.7 \%$ & $46.2 \%$ & $53.6 \%$ & $60.4 \%$ & $40.7 \%$ \\
\hline 6 & $29.1 \%$ & $20.0 \%$ & $29.2 \%$ & $31.4 \%$ & $50.0 \%$ & & $36.0 \%$ & $64.3 \%$ & $50.0 \%$ & $46.2 \%$ & $57.1 \%$ & $56.0 \%$ \\
\hline 7 & $44.9 \%$ & $12.5 \%$ & $26.1 \%$ & $32.7 \%$ & $40.7 \%$ & $36.0 \%$ & & $55.6 \%$ & $56.5 \%$ & $60.0 \%$ & $51.1 \%$ & $45.8 \%$ \\
\hline 8 & $43.6 \%$ & $21.8 \%$ & $30.8 \%$ & $32.7 \%$ & $46.7 \%$ & $64.3 \%$ & $55.6 \%$ & & $53.8 \%$ & $67.9 \%$ & $60.4 \%$ & $66.7 \%$ \\
\hline 9 & $46.8 \%$ & $8.7 \%$ & $22.7 \%$ & $29.8 \%$ & $46.2 \%$ & $50.0 \%$ & $56.5 \%$ & $53.8 \%$ & & $62.5 \%$ & $62.2 \%$ & $52.2 \%$ \\
\hline 10 & $43.1 \%$ & $24.0 \%$ & $33.3 \%$ & $39.2 \%$ & $53.6 \%$ & $46.2 \%$ & $60.0 \%$ & $67.9 \%$ & $62.5 \%$ & & $77.6 \%$ & $64.0 \%$ \\
\hline 11 & $41.7 \%$ & $8.5 \%$ & $31.1 \%$ & $33.3 \%$ & $60.4 \%$ & $57.1 \%$ & $51.1 \%$ & $60.4 \%$ & $62.2 \%$ & $77.6 \%$ & & $63.8 \%$ \\
\hline 12 & $36.7 \%$ & $16.7 \%$ & $17.4 \%$ & $28.6 \%$ & $40.7 \%$ & $56.0 \%$ & $45.8 \%$ & $66.7 \%$ & $52.2 \%$ & $64.0 \%$ & $63.8 \%$ & \\
\hline
\end{tabular}

Tab. 7. Sørensen similarity indeks beetwen caddisfly fauna in different locations in the Plitvice Lakes NP (all data): 1 - spring of Bijela rijeka, 2 - spring of Crna rijeka; 3 - stream Bijela Rijeka - middle part, 4 - stream Crna Rijeka - middle part, 5 - stream Plitvica - lower part, 6 - River Korana - upper part; 7 - Prošćansko Lake, 8 -- Galovac Lake, 9 - Kozjak Lake, 10 - tufa barrier Labudovac, 11 - tufa barrier Kozjak/Milanovac, 12 - tufa barrier Novakovića Brod.

\begin{tabular}{|c|c|c|c|c|c|c|c|c|c|c|c|c|}
\hline Sites & 1 & 2 & 3 & 4 & 5 & 6 & 7 & 8 & 9 & 10 & 11 & 12 \\
\hline 1 & & $48.3 \%$ & $45.3 \%$ & $50.0 \%$ & $42.6 \%$ & $27.6 \%$ & $39.3 \%$ & $39.3 \%$ & $41.5 \%$ & $38.9 \%$ & $30.8 \%$ & $35.8 \%$ \\
\hline 2 & $48.3 \%$ & & $53.1 \%$ & $57.1 \%$ & $35.1 \%$ & $18.5 \%$ & $11.5 \%$ & $21.1 \%$ & $8.2 \%$ & $29.4 \%$ & $9.8 \%$ & $19.1 \%$ \\
\hline 3 & $45.3 \%$ & $53.1 \%$ & & $70.6 \%$ & $50.0 \%$ & $28.6 \%$ & $25.5 \%$ & $30.8 \%$ & $22.7 \%$ & $34.9 \%$ & $28.6 \%$ & $17.2 \%$ \\
\hline 4 & $50.0 \%$ & $57.1 \%$ & $70.6 \%$ & & $57.6 \%$ & $32.1 \%$ & $29.6 \%$ & $33.9 \%$ & $27.5 \%$ & $40.0 \%$ & $28.6 \%$ & $27.7 \%$ \\
\hline 5 & $42.6 \%$ & $35.1 \%$ & $50.0 \%$ & $57.6 \%$ & & $49.1 \%$ & $40.0 \%$ & $46.7 \%$ & $46.2 \%$ & $56.3 \%$ & $53.1 \%$ & $39.4 \%$ \\
\hline 6 & $27.6 \%$ & $18.5 \%$ & $28.6 \%$ & $32.1 \%$ & $49.1 \%$ & & $34.6 \%$ & $63.2 \%$ & $49.0 \%$ & $52.9 \%$ & $62.3 \%$ & $50.8 \%$ \\
\hline 7 & $39.3 \%$ & $11.5 \%$ & $25.5 \%$ & $29.6 \%$ & $40.0 \%$ & $34.6 \%$ & & $54.6 \%$ & $55.3 \%$ & $54.6 \%$ & $44.1 \%$ & $52.5 \%$ \\
\hline 8 & $39.3 \%$ & $21.1 \%$ & $30.8 \%$ & $33.9 \%$ & $46.7 \%$ & $63.2 \%$ & $54.6 \%$ & & $53.9 \%$ & $70.4 \%$ & $62.5 \%$ & $63.6 \%$ \\
\hline 9 & $41.5 \%$ & $8.2 \%$ & $22.7 \%$ & $27.5 \%$ & $46.2 \%$ & $49.0 \%$ & $55.3 \%$ & $53.9 \%$ & & $54.0 \%$ & $57.1 \%$ & $44.8 \%$ \\
\hline 10 & $38.9 \%$ & $29.4 \%$ & $34.9 \%$ & $40.0 \%$ & $56.3 \%$ & $52.9 \%$ & $54.6 \%$ & $70.4 \%$ & $54.0 \%$ & & $74.7 \%$ & $67.5 \%$ \\
\hline 11 & $30.8 \%$ & $9.8 \%$ & $28.6 \%$ & $28.6 \%$ & $53.1 \%$ & $62.3 \%$ & $44.1 \%$ & $62.5 \%$ & $57.1 \%$ & $74.7 \%$ & & $62.9 \%$ \\
\hline 12 & $35.8 \%$ & $19.1 \%$ & $17.2 \%$ & $27.7 \%$ & $39.4 \%$ & $50.8 \%$ & $52.5 \%$ & $63.6 \%$ & $44.8 \%$ & $67.5 \%$ & $62.9 \%$ & \\
\hline
\end{tabular}

only one locality (e.g. G. bifidum Mclachlan, H. cognata Mosley, H. rheni Ris, G. pilosa Fabricius, H. infumatus McLachlan), which will probably change during future studies.

The above hypotheses become significantly important when we compare the caddisfly fauna in the Plitvice Lakes NP to that of other well-investigated areas in Croatia. For example, in the area of the Cetina river (105 km long, ŠTAmbuk-Giljanović, 2006) 70 caddisfly species have been recorded (GraF et al., 2008a; WARINGer et al., 2009; VučKović, 2011; MaLICKY, 2014) while in the area of the Krka river (73 km long, BERTić et al., 2001), also a Mediterranean river, we found 51 species (Kučınıć et al., 2011; Ridu et al., 2017). In the River Dobra (104 km long, BERTić et al., 2001) situated in the central mountainous part of Croatia, about 60 cadisflies species have been identified (Cerjanec, 2012; Previšić et al., 2012). The Plitvice Lakes with a length of $9 \mathrm{~km}$ are a relatively short hydrosystem, so the high biodiversity of Trichoptera species is very interesting when we consider the extent of habitat in relation to its biodiversity. The complete study of other groups of freshwater organisms, including aquatic insects, will show whether these conclusions about biodiversity and specificity of the Plitvice Lakes will be reflected in them as well. 
Tab. 8. Number of caddisflies species found in different type of habitats in the Plitvice Lakes NP.

\begin{tabular}{|l|c|}
\hline Habitats & Number of species \\
\hline Springs & 44 \\
\hline Streams & 56 \\
\hline Lakes & 45 \\
\hline Tufa barriers & 56 \\
\hline
\end{tabular}

Tab. 9. Sørensen similarity index of caddisfly fauna between different types of habitats in the Plitvice Lakes NP.

\begin{tabular}{|c|c|c|c|c|}
\hline Habitats & Springs & Streams & Lakes & Tufa barriers \\
\hline Springs & - & $54 \%$ & $47.1 \%$ & $48.0 \%$ \\
\hline Streams & - & - & $63.3 \%$ & $64.3 \%$ \\
\hline Lakes & - & - & - & $73.2 \%$ \\
\hline Tufa barriers & - & - & - & - \\
\hline
\end{tabular}

\section{Ecological features of caddisflies in the Plitvice Lake NP: emergence features and flight periods}

After 2000 and 2001, studies with pyramid-type emergence traps continued in 2007, and at a few localities it is still ongoing (e.g. ŠEмNičKI et al., 2011, 2012; Ivкоvić et al., 2013b; Previšŕć et al., 2013). As a result of these investigations the number of Trichoptera species significantly increased in the studies sites as well as in the area of the National Park. Those findings show not only the value of the pyramid-type emergence trap method but also the significance of long-term studies in a particular area with the aim of defining not only ecological but also faunistic characteristics of a certain segment of the fauna. This can be confirmed with the first findings of Apatania muliebris Mcachlan and Hydroptila rheni Ris. in the Croatian fauna using pyramid emergence traps on the Bijela Rijeka spring and the upper flow of the Korana river (PREvišić et al., 2013). Some other groups of aquatic insects confirm that, too (Ivкоvić et al., 2013a, 2015; Kvifte et al., 2013). These results enabled the descriptions of Berdeniella keroveci Kvifte \& Ivković (Diptera, family Psychodidae) (Kvifte et al., 2013) which might be the first such case in Europe, as well as the description of C. bucari Kučinić, Szivák \& Delić from Banovina (Kučinić et al., 2013).

The highest number of species was found in summer (61 species in June, 51 species in July) while some species were found only in spring (e.g. R. alpestris Kolenati, B. minutus Linnaeus) and in autumn and winter (e.g. genera Chaetopteryx, Potamophylax) (Tab. 10). February was the only month without recorded cadisfly flight activity (Tab. 10). The flight activity of caddisflies in Plitvice Lakes NP started in March $(R$. fasciata Hagen) and April (12 determined species) (Tab. 10). The species with the longest emergence and flight periods in the Plitvice Lakes NP are Rhyacophila fasciata Hagen, $R$. aurata Brauer, Wormaldia subnigra McLachlan, D. croaticus Marinković-Gospodnetić and Potamophylax latipennis Curtis (Tab. 10), which is due to their biological and habitat characteristics. For subfamily Drusinae, inhabiting only the springs and crenal parts of streams, the long period of emergence and the presence of adults is triggered by the constant low water temperature which does not show any significant seasonal changes, unlike other parts of the streams or other sites in the Plitvice Lakes NP (Kučinıć, 2002; Ivкоvić et al., 2015). The longest flight period during 9 months was recorded for $R$. fasciata Hagen, 1859 (Tab. 10). Similar patterns were also observed in other parts of Croatia and it is an ecological and biological characteristic of $R$. fasciata (e.g. Svensson, 1972; VučKović et al., 2011; CeRJANeC, 2012). According to ОтTо (1981), caddisflies with predatory larvae have food resources during the whole year and have the possibility of a long emergence and flight period, like $R$. fasciata or $R$. aurata with flight period on Plitvice Lakes of 8 months. On the other hand, in the Plitvice Lakes NP 22 species was recorded only during one month, 15 species were collected during two months and 18 species were detected during three months (Tab. 10). For the remaining 36 species the flight period was longer than four months (Tab. 10).

For the determination of specific emergence periods the emergence trap data are very important. The use of light traps can, however, be quite misleading. Species with long adult period lives (NovaK \& SEHNAL, 1962) can emerge in one month but be collected in the following or later months, so records of 
Tab. 10. Flight periods of caddisfly species in the Plitvice Lakes NP ( $=$ female).

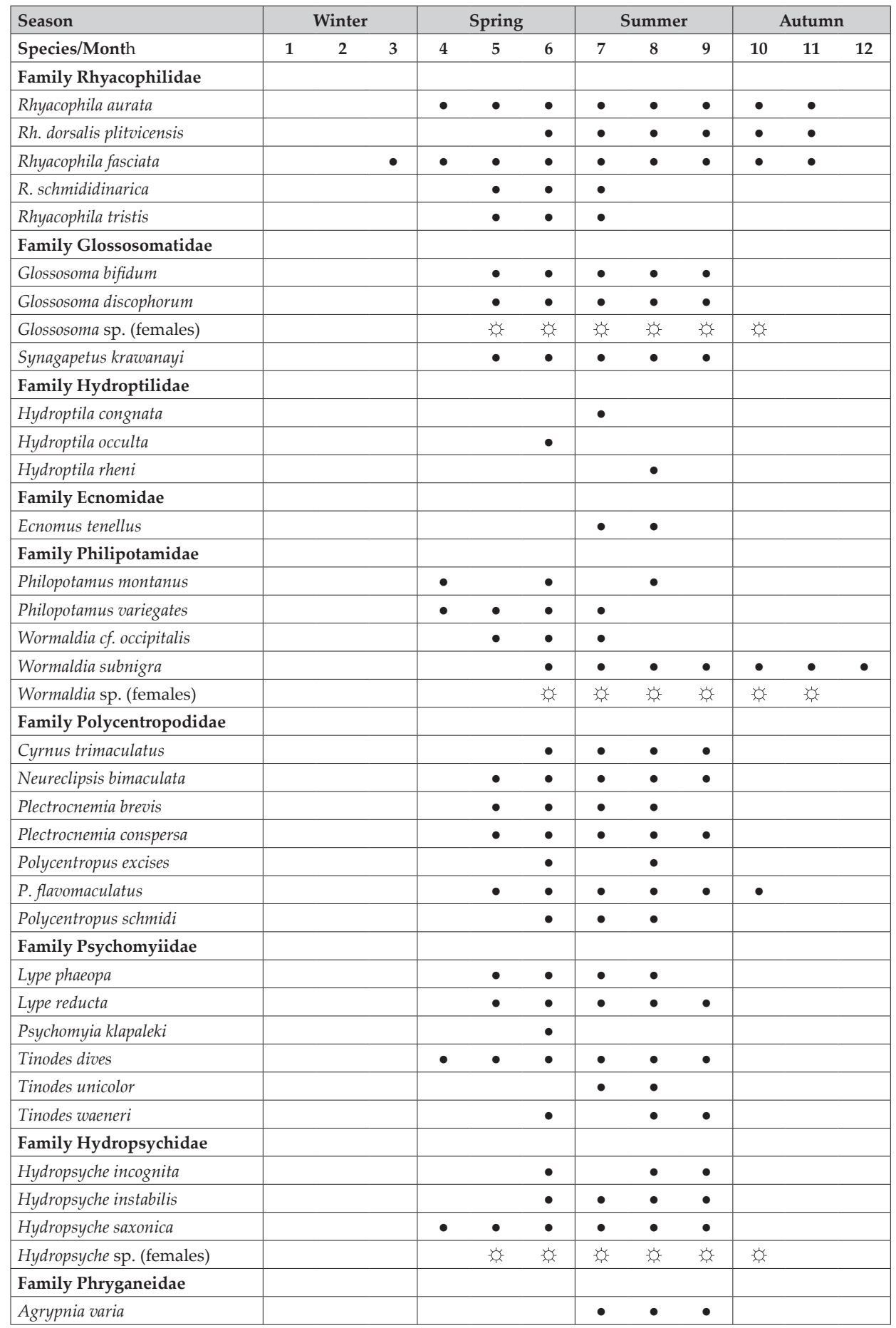


244 Kučinić, M. et al.: First systematic investigation of adults and second checklist of caddisflies of the Plitvice Lakes...

\begin{tabular}{|c|c|c|c|c|c|c|c|c|c|}
\hline Season & Winter & \multicolumn{3}{|c|}{ Spring } & \multicolumn{3}{|c|}{ Summer } & \multicolumn{2}{|r|}{ Autumn } \\
\hline Phryganea bipunctata & & & & $\bullet$ & & & & & \\
\hline Phryganea grandis & & & & & $\bullet$ & $\bullet$ & & & \\
\hline \multicolumn{10}{|l|}{ Family Goeridae } \\
\hline Goera pilosa & & & & $\bullet$ & & & & & \\
\hline Litax niger & & $\bullet$ & $\bullet$ & $\bullet$ & & & & & \\
\hline Silo pallipes & & & $\bullet$ & $\bullet$ & $\bullet$ & $\bullet$ & & & \\
\hline \multicolumn{10}{|l|}{ Family Lepidostomatidae } \\
\hline Lepidostoma hirtum & & & $\bullet$ & $\bullet$ & $\bullet$ & $\bullet$ & $\bullet$ & $\bullet$ & \\
\hline Crunoecia kempnyi & & & & $\bullet$ & & & & & \\
\hline \multicolumn{10}{|l|}{ Family Limnephilidae } \\
\hline Apatania muliebris & & $\bullet$ & $\bullet$ & & & & & & \\
\hline Drusus croaticus & & & - & $\bullet$ & $\bullet$ & $\bullet$ & $\bullet$ & $\bullet$ & $\bullet$ \\
\hline Rhadicoleptus alpestris & & & $\bullet$ & & & & & & \\
\hline Limnephilus affinis & & & $\bullet$ & & & & & & \\
\hline Limnephilus auricula & & $\bullet$ & $\bullet$ & $\bullet$ & $\bullet$ & & $\bullet$ & & \\
\hline Limnephilusn extricates & & & & $\bullet$ & & $\bullet$ & & & \\
\hline Limnephilus flavicornis & & & & & $\bullet$ & $\bullet$ & $\bullet$ & & \\
\hline Limnephilus hirsutus & & & & & & & $\bullet$ & & \\
\hline Limnephilus ignavus & & & & & & $\bullet$ & $\bullet$ & & \\
\hline Limnephilus lunatus & & & - & $\bullet$ & $\bullet$ & $\bullet$ & $\bullet$ & $\bullet$ & \\
\hline Limnephilus rhombicus & & & $\bullet$ & $\bullet$ & $\bullet$ & $\bullet$ & $\bullet$ & & \\
\hline Limnephilus sparsus & & & & & & $\bullet$ & $\bullet$ & & \\
\hline Chaetopteryx fusca & $\bullet$ & & & 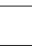 & & & $\bullet$ & $\bullet$ & \\
\hline Chaetopteryx gonospina & & & & & & & $\bullet$ & & \\
\hline Grammotaulius nigropunctatus & & & $\bullet$ & $\bullet$ & $\bullet$ & & & & \\
\hline Glyphotaelius pellucidus & & $\bullet$ & $\bullet$ & $\bullet$ & $\bullet$ & $\bullet$ & $\bullet$ & $\bullet$ & \\
\hline Micropterna lateralis & & & $\bullet$ & & & & & & \\
\hline Micropterna nycterobia & & & & & & & $\bullet$ & $\bullet$ & \\
\hline Micropterna sequax & & & & • & & & $\bullet$ & $\bullet$ & \\
\hline Stenophylax permistus & & $\bullet$ & $\bullet$ & $\bullet$ & & $\bullet$ & $\bullet$ & $\bullet$ & \\
\hline Stenophylax vibex & & & $\bullet$ & & & & & & \\
\hline Potamophylax latipennis & & $\bullet$ & $\bullet$ & $\bullet$ & $\bullet$ & $\bullet$ & $\bullet$ & $\bullet$ & \\
\hline Potamophylax luctuosus & & & & & & & $\bullet$ & & \\
\hline Potamophylax nigricornis & & & & $\bullet$ & $\bullet$ & & $\bullet$ & & \\
\hline Potamophylax pallidus & & & & & & $\bullet$ & $\bullet$ & $\bullet$ & \\
\hline Potamophylax rotundipennis & & & & & & & $\bullet$ & $\bullet$ & \\
\hline Allogamus uncatus & & & & & & & $\bullet$ & $\bullet$ & $\bullet$ \\
\hline Halesus digitatus & & & & & & & $\bullet$ & $\bullet$ & \\
\hline Halesus tesselatus & & & & & & & $\bullet$ & $\bullet$ & \\
\hline Hydatophylax infumatus & & & & $\bullet$ & & & & & \\
\hline \multicolumn{10}{|l|}{ Family Sericostomatidae } \\
\hline Notidobia ciliaris & & & $\bullet$ & & $\bullet$ & & & & \\
\hline Sericostoma flavicorne & & & $\bullet$ & $\bullet$ & $\bullet$ & & & & \\
\hline \multicolumn{10}{|l|}{ Family Odontoceridae } \\
\hline Odontocerum albicorne & & & & $\bullet$ & $\bullet$ & $\bullet$ & & & \\
\hline \multicolumn{10}{|l|}{ Family Beraeidae } \\
\hline Beraea pullata & & & & $\bullet$ & & & & & \\
\hline
\end{tabular}




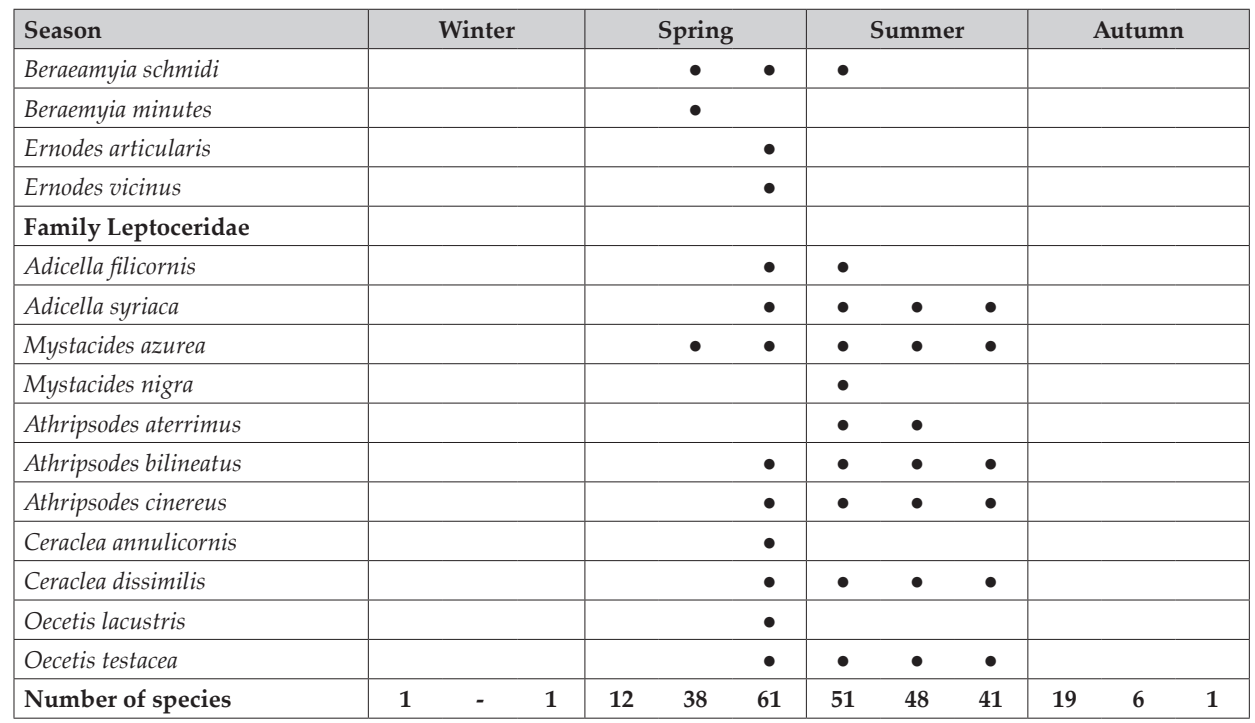

adults alone do not define the duration of a life cycle and the periods of emergence for that species (Kučinić, 2002). Many studies have shown that duration of the flight periods and emergence periods differ in several cases (Hickin, 1967; Svensson, 1972; Kučinić, 2002; Previšić et al., 2007). Thus, every method is limited by certain parameters that must be taken into account when data are interpreted (ILLIES, 1971; Malicky, 2002a, 2002b; WAgner \& SChMidt, 2004; Previšić et al. 2007).

\section{CONCLUSION}

The great diversity of aquatic habitats in the Plitvice Lakes NP significantly contributes to the caddisfly fauna biodiversity. These diverse habitats enable the formation of specific microhabitats, provide all food types for caddisflies (GRAF et al., 2008) and ensure the exploitation of energy resources which is important for their speciation, evolution and biodiversity (PAuls et al., 2008; ViteceK et al., 2015).

The area of the Plitvice Lakes NP is very suitable for long-term biomonitoring and the investigation of various aspects of Trichoptera biology as well as of other groups of aquatic and terrestrial invertebrates. Several research projects that are currently being conducted in the Plitvice Lakes NP, as well as the analysis of the previously collected material, should give not only a better understanding of the organisms present in this area but also an insight into the geological and biological processes that shape the aquatic and terrestrial habitats of the Plitvice Lakes.

Due to the complexity and sensitivity of the Plitvice Lakes system, it is extremely important to ensure appropriate protection of that area when future research is performed. Moreover, the area of the National Park should be used appropriately for the benefits of the local community. Considering visitors, a strong protection of this extremely valuable area should be ensured.

\section{ACKNOWLEDGEMENTS}

This research was supported by the University of Zagreb, the Croatian Natural History Museum, the Plitvice Lakes National Park, the Ministry of Science and Education of the Republic of Croatia, the Ministry of Culture of the Republic of Croatia, and the City Office for Education, Culture and Sport of City of Zagreb. Special thanks to colleague Slavko Vuković, employee of the Plitvice Lakes NP for his great and unconditional help during all field work. Also, thanks to colleagues Nenad Vajdić and Branko Jalžić from the Croatian Natural History Museum in Zagreb, Tomislav Domazet Lošo from the Institute Ruđer Bošković, Mladen Plantak from the Elektroprojekt, and to Vilko Plavec and Hrvoje Plavec. Also great thanks to three anonymous reviewers for many useful suggestions and comments in the manuscript. 


\section{REFERENCES}

BARquin, J. \& DeAth, R. G., 2006: Spatial patterns of macroinvertebrate diversity in New Zeland spring brooks and rhitral streams. North American Bent. Soc. 25, 768-786.

Bednar, J. P., Trobej, M., Schagerl M. \& Waringer, J., 2017: Which factors shape macrozoobenthic communities in tufa springs? Results from Austrian meteogene travertine-depositing sites. Hydrobiologia 799, 293-307. DOI 10.1007/s10750-017-3228-x

Belančić, A., MatoničKin Kepčija, R., Miliša, M., Plenković-Moraj, A. \& Habdija, I., 2009: Flov velocity effect on elaf litter breakdown int ufa depositing system (Plitvice Lakes, Croatia). International Review of Hydrobiology 94, 391-398.

Bertić I., LAmpek PavčNik, I. \& Radovinovićı, R., 2001: Satelitski atlas Hrvatske. Naklada Ljevak i Gisdata, Zagreb, 360 pp.

Brooks, A.J., Haeusler, T. \& Reinfelds \& Williams, S., 2005: Hydraulic microhabitats and the distribution of macroinvertebrate assemblages in riffles. Freshwater Biolology 50, 331-344.

Caput, K. \& Plenković-MoraJ, A., 2000: Epiphytic diatoms on sawgrass (Cladium mariscus) in the Plitvice Lakes, Croatia. Biologia 55, 343-350.

Cerjanec, D., 2012: Ekološke i biogeografske značajke faune tulara (Insecta: Trichoptera) u različitim tipovima staništa sliva rijeke Dobre. Doktorska disertacija (PhD Thesis), Faculty of Science, University of Zagreb, Zagreb, 172 pp.

Dražina, T., Šroljar, M., Primc, B. \& Habdija, I., 2013: Small-scale patterns of meiofauna in bryophyte covered tufa barrier (Plitvice Lakes, Croatia). Limnologica 43, 405-416. DOI: 10.1016/j.limno.2013.01.004

Edington, J.M. \& Hildrew, A.G.: 1995: A revised key to the caseless caddis larvae oft he BritishIsels with notes on their ecology. FBA Scientific Publication, 54, 1-134.

Ford, T. D. \& Pedley, H.M., 1996: A rewiev of tufa and travertine deposits of the world. Earth-Science Reviews 41, 117-175.

FrančišKović-Bilinski, S., BArišić, D., A. Vertačnik, A., Bilinski, H. \& Prohić, E., 2004: Characterization of tufa from the Dinaric Karst of Croatia: mineralogy, geochemistry and discussion of climate conditions. Facies 50, 183-193.

Golubić, S., 1969: Cyclic and non-cyclic mechanisms in the formation of travertine. Verh. International Verein. Limnology 17, 956-961.

Golubić, S., Violante, C., Plenković-Moraj, A. \& T. Grgasović, 2008: Travertines and calcareous tufa deposits: an insight into diagenesis. Geologia Croatica 61, 363-378.

Graf, W., Kučinić, M., Previšić, A,. VučKović, I. \& Waringer, J. 2008a: The Larva, ecology and distribution of Tinodes braueri McLachlan, 1878 (Trichoptera: Psychomyiidae). Aquatic insects 30, 295-299.

Graf, W., Murphy, J., Dahl, J., Zamora-Muñoz, C. \& López-Rodríguez, M. J., 2008b: Distribution and ecological preferences of European freshwater organisms. Volume 1. Trichoptera. Pensoft, Sofia-Moscow, 388 pp.

HabdijA, I., 1989: Trophic importance of trichopterous larvae in benthos oft he lakes Plitvice. Periodicum Biologorum 90, 355-361.

Habdija, I., Primc-Habdija, B. \& Belinić, I., 1994: Functional community organization of macroinvertebrates in lothic habitats of the Plitvice Lakes. Acta Hydrochimica et Hydrobiologica 22, 85-92.

Habdija, I., Primc-Habdija, B., MatoničKin, R., Kučinić, M., Radanović, I., Miliša, M. \& Mihaljević, Z., 2004: Current velocity and food supply as factors affecting the composition of macroinvertebrates in bryophyte habitats in karst running water. Biologia 59, 577-593.

Hickin, N. E., 1967: Caddis Larvae. Hutchinson, London, 476 pp.

Holzenthal, R. W, Blahnik, R. J., Prather, A. L . \& KJer, K M., 2007: Order Trichoptera Kirby, 1813 (Insecta), Caddisflies. Zootaxa 1668, 639-698.

HršAK, V., ŠEgulja, N. \& Dujmović, A., 2004: Promjene u kemijskim svojstvima tla na trajnim plohama travnjačke vegetacije u Nacionalnom parku Plitvička jezera od godine 1989. do 2002. Plitvički bilten (Radovi), 6, 129-140.

ILliES, J., 1971: Emergenz 1969 in Breitenbach, Schlitzer produktionsbiologische Studien (1) (Emergence 1969 on Breitenbach (Schlitz studies on productivity No. I)). A Archiv für Hydrobiologie 69, 14-59.

Ivкović, M., Mičetić Stanković, V. \& Mihaljević, Z., 2012: Emergence patterns and microhabitat preference of aquatic dance flies (Empididae; Clinocerinae and Hemerodromiinae) on a longitudinal gradient of barrage lake system. Limnologica $42,43-49$. 
Ivкović, M, Kesić, M, Mihaljević, Z. \& Kúdela M. 2013a: Emergence patterns and ecological associations of some haematophagous blackfly species along an oligotrophic hydrosystem. Med. Vet. Entomol 28, 94-102. doi:10.1111/mve.12019

Ivković, M, Miliša, M.., Previšić, A., Popijač, A. \& Mihaljević, Z., 2013b: Environmental control of emergence patterns: case study of change sin hourly and daily emergence of aquatic insects at constant and variable water temperatures. International Review of Hydrobiology 98, 104-115.

Ivković, M., Miliša, M., Baranov, V. \& Mihaljević, Z., 2015: Environmental drivers of biotic traits and phenology patterns of Diptera assemblages in karst springs: The role of canopy uncovered. Limnologica 54, 44-57.

Johnson, R. K., Goedkoop, W. \& SAndin, L., 2004: Spatial scale and ecological relationships between the macroinvertebrate communities of stony habitats of streams and lakes. Freshwater Biology 49, 11791194.

KLAPÁLEK, F., 1906: Ein Beitrag zur Kenntnis dre Neuropteroiden-Fauna von Croatia-Slavonien und der Nachbarländer. Bulletin International (Académie des Sciences de lempereur François Joseph I.) 11, 77-85.

Kostić-Brnek, Lj. \& Brnek-Kostić, A., 1974: Vode Nacionalnog parka Plitvička jezera i život u njima (in Croatian). In Gušić, B. \& M. Marković (eds), Plitvička jezera - čovjek i priroda. National Park Plitvice Lakes, Zagreb, 37-49.

KRUŠNIK, C., 1987: Trichoptera (Insecta). Fauna Durmitora 2, 201-224.

Kučınıć, M., 2002: Diversity and distribution of caddisfles in Plitvička Lakes. PhD Thesis (on Croatian), Zagreb, Croatia: University of Zagreb, Zagreb, 139 pp.

Kučınić, M. \& Ilıć, D., 1993: Micropterna testacea Gmelin 1789 (Insecta, Trichoptera) nova vrsta u fauni tulara Republike Hrvatske. Rad HAZU 26, 125-131.

Kučinić, M. \& Malicky, H., 2002: Rhyacophila dorsalis plitvicensis new subspecies from Croatia. Proceedings of the $10^{\text {th }}$ International Symposium on Trichoptera (Ed. W. MEY). Nova Supplementa Entomologica 15, 145-147.

Kučinić, M., Previšić, A., Gottstein, A., Hrašovec, B., Stanić-Koštroman, S., Pernek, M. \& Delić, A., 2008: Description of the larvae of Drusus radovanovici septentrionis Marinković-Gospodnetić, 1976 and Drusus croaticus Marinković-Gospodnetić, 1971 (Trichoptera: Limnephilidae) from Bosnia and Herzegovina and Croatia. Zootaxa, 1783, 1-17.

Kučinić, M., Vučković, I., Kutnjak, H., Šerić Jelaska, L. \& Marguš, D., 2011: Diversity, distribution, ecology and biogeography of caddisflies (Insecta: Trichoptera) in the Krka River (National Park "Krka", Croatia). Zoosymposia 5, 255-268.

Kučinić, M., Szivák, I., Pauls, S.U., BÁlint, M., Delić, A. \& VučKović, I., 2013: Chaetopteryx bucari sp. n. a new species from the Chaetopteryx rugulosa group from Croatia (Insecta, Trichoptera) with some molecular, taxonomical and ecological notes on the group. Zookeys 320, 1-28.

Kučinić, M., Previšić, A., Mihoci, I., Krpač, V., Žıvić, I., Stojanović, K., Mrnjavčić Vojvoda, A. \& Katušić, L., 2016: Morphological features of larvae of Drusus plicatus Radovanović (Insecta, Trichoptera) from the Republic of Macedonia with molecular, ecological, ethological and distributional notes. Zookeys 598, 75-97.

Kumanski, K. P., 1988: Trichoptera, Integripalpia. Fauna Bulgarica 19, 1-354.

Kvifte, M. G., Ivković, M. \& Klarić, A., 2013: New records of moths (Diptera: Psychodide) from Croatia with description of Berdeniella keroveci sp. nov. Zootaxa 3537, 57-67.

Langhoffer, A., 1915: Fauna hrvatskih pećina, II. (Fauna cavernarum Croatiae II). Prirodoslovna istraživanja Hrvatske i Slavonije 7, 3-22.

Lukač, G., 2004: Ptice nacionalnog parka Plitvička jezera. Plitvički bilten (Radovi), 6, 29-70.

Makjanić, B., 1972: Climate of the Plitvice Lakes Area. Hrvatski geografski glasnik 33-34, 5-23.

Malicky, H., 2002a: A quantitative field comparison of different types of emergence traps in a stream: general, Trichoptera, Diptera (Limoniidae and Empididae). Annales de Limnologie 38, 133-149.

MaLicky, H., 2002b: A quantitative field comparison of emergence traps with open and covered bottoms in a stream: general and Trichoptera. Annales de Limnologie 38, 241-246.

Malicky, H., 2002c: The sub-specific diovision of Rhyacophila dorsalis Curtis, 1834 and its transitions to R. nubila Zetterstedt, 1840 (Trichoptera: Rhyacophilidae). Proceedings of the $10^{\text {th }}$ International Symposium on Trichoptera (Ed. W. Mey). Nova Supplementa Entomologica, 15, 149-166.

Malicky, H., 2004: Atlas of European Trichoptera. Springer, Dordrecht, 384 pp.

MaLICKY, H., 2014: Leebnsräume von Köcherfliegen (Trichoptera). Denisia 34, 1-280. 
Marinković-Gospodnetić, M., 1971: The species of the genus Drusus in Yugoslavia.Godišnjak Biološkog Instituta Univerziteta Sarajevo (Annual of the Institute of Biology - University of Sarajevo) 24, 105-109.

Marinković-Gospodnetić, M., 1979: Trichoptera (Insecta) velikih karstnih izvora u Dinaridima. In: RAuš, Đ. (Ed.), Drugi kongres Ekologa Jugoslavije (Second Congress of Ecologists of Yugoslavia). Savez društava ekologa Jugoslavije. Zagreb, pp. 1837-1849.

Matić, N., Maldini, K., Tomas, D., Ćuk, R., Milović, S., Miklavčić, I. \& ŠIrac, S., 2016: Geochemical characteristics of the Gacka River karstic springs (Dinaric karst, Croatia) with macroinvertebrate assemblages overview. Environ. Earth Sci., 75, 1308. DOI 10.1007/s12665-016-6087-2

MatoničKın, I., 1959: Faunistička istraživanja reikotopnih biotopa na Plitvičkim jezerima. Ljetopis knjiga 63, 355-360.

MatoničKın, I., 1987: Građa za Limnofaunu krških voda tekućica Hrvatske, Plitvička jezera. Biosistematika 13, 25-35.

MatoničKin, I. \& Pavletić, Z., 1961: Biljni i životinjski svijet na sedrenim slapovima jugoslavenskih krških voda. Biološki glasnik 14, 105-127.

MatoničKin, I. \& PAvletić, Z., 1967: Hidrologija potočnog sistema Plitvičkih jezera i njegove biocenološke značajke. Krš Jugoslavije 5, 83-126.

MatoničKin, I., PAvletić, Z., Tavčar, V. \& KRKač, N., 1971: Limnološka istraživanja reikotioopa i fenomena protočne travertinizacije u Plitvičkim jezerima. Prirodoslovna istraživanja JAZU 40, Acta Biologica 7, 1-88.

Mičetić Stanković, V., JÄch, M. \& Kučınić, M., 2015: Annotated checklist of Croatian riffle beetles (Insecta: Coleoptera: Elmidae). Natura Croatica 24, 93-109.

Miliša, M., Habdija, I., Primc-Habdija, B., Radanović, I. \& MatoničKin Kepčija, R., 2006: The role of flow velocity in the vertical distribution of particulate organic matter on moss-covered travertine barriers of the Plitvice Lakes (Croatia). Hydrobiologia 553, 231-243.

MilišA, M., Ivкоvić, M. \& MatoničKin KepčijA, R., 2014: Energy resources and feeding guild structure of macroinvertebrate in the hyporeic zone of calcite deposting lake outlets. Limnologica 44, 66-71.

Morrse, J., 2017: Trichoptera World Checklist. http://entweb.clemson.edu/database/trichopt/index.htm [accessed 24 November 2017].

Neu, P., 2015: Anmerkungen zu „Wormaldia occipitalis Pictet, 1834“ (Trichoptera, Philopotamidae). Lauterbornia 79, 107-124.

NosiL, P., 2012: Ecological Speciation. Oxford Series in Ecology and Evolution, Oxford University Press, 304 pp.

NovaK, K. \& SeHnal, F., 1962: The development cycle of some species of the genus Limnephilus (Trichoptera). Časopis Československe Společnosti Entomologicke 1-2, 68-80.

Отто, С., 1981: Why does duration of flight periods differ in caddisflies? Oikos 37, 383-386.

Pauls, S. U., Graf, W., HaAse, P., Lumbsch, H. T. \& Waringer, J., 2008: Grazers, shredders and filtering carnivores - the evolution of feeding ecology in Drusinae (Trichoptera: Limnephilidae. Insights from a molecular phylogeny. Molecular Phylogenetic and Evolution 46, 776-791. doi: 10.1016/j.ympev.2007.11.003

Pentecost, A., 2005: Travertine, Berlin, Heidelberg. Springer-Verlag, New York, 445 pp.

Petrik, M., 1958. Prinosi hidrologiji Plitvica. Poljoprivredni nakladni zavod, Zagreb.

Plenković-Moraj, A., Horvatinčić, N. \& Primc-Habdija, B., 2002: Periphyton and its role in tufa deposition in karstic water (Plitvice lakes, Croatia. Biologia 57, 423-431.

Popijač, A. \& Sivec, I., 2009: Diversity and distribution of stoneflies in the area of Plitvice Lakes National Park and along the Mediterranean river Cetina (Croatia). In: STANICZEK AH (ed.) International Perspectives in Mayfly and Stonefly Research, Proceedings of the 12th International Conference on Ephemeroptera and the 16th International Symposium on Plecoptera, Stuttgart, 2008. Aquatic Insects 31, 731-742.

Previšić, A., Kerovec, M. \& Kučinić, M., 2007: Emergence and Composition of Trichoptera from Karst Habitans, Plitvice lakes Region, Croatia. International Review of Hydrobiology 92, 61-83.

Previšić, A., Walton, C., Kučinić, M., Mitrikeski, P.T. \& Kerovec, M., 2009: Pleistocene divergence of Dinaric Drusus endemics (Trichoptera, Limnephilidae) in multiple microrefugia within the Balkan Peninsula. Molecular Ecolgy 18, 634-647. doi: 10.1111/j.1365-294X.2008.04046.x

Previšić, A., Graf, W. \& Kučinić, M., 2010: Caddisfly (Trichoptera) fauna of the Plitvice Lakes National Park, Croatia. Denisia 29, 287-294. 
Previšić, A., Cerjanec D., Graf W. \& Kučinić, M., 2012: Drusus chrysotus (R8ambur, 1842) (Trichoptera: Limnephilidae: Drusinae): a new caddisfly species in the Croatian fauna. Natura Croatica 21, 419-425.

Previšić, A., Dvorski, P., Cetinić, K \& Ivković, M., 2013: New records for the Croatian caddisfly (Trichoptera, Insecta) fauna from the Plitvice Lakes national Parka. Entomologia Croatica 13, 7-12.

Previšić, A., Schnitzler, J., Kučinić, M., Graf, W., Ibrahimi, H., Kerovec, M. \& Pauls, S. U., 2014: MicroScale Vicariance and Diversification of Western Balkan Caddisflies Linked to Karstification. Freshwater Science 33, 250-262.

Primc-Habdija, B., Habdija, B. \& Plenković-Moraj, A., 2001: Tufa deposition and periphyton overgrowth as factors affecting the ciliate community on travertine barriers in different current velocity conditions. Hydrobiologia 457, 87-96.

Ridl, A., Previšić, A., Ivković, M. \& Mihaljević, Z., 2017: Emergencija tulara (Trichoptera, Insecta) sedrenih barijera u NP »Krka«. Zbornik radova Znanstveno-stručniog skupa »Vizija i izazovi upravljanja zaštićenim područjima prirode u Republici Hrvatskoj: Aktivna zaštita i održivo upravljanje u Nacionalnom parku »Krka« $(u$ tisku).

RiĐAnović, J. \& Božıćević, S., 1996: Geographic-physical conditions of runoff and hydrogeological characteristics of the Plitvice Lakes. Acta Geographica Croatica 31, 7-26.

Sertić Perić, M., Miliša, M., Matoničkin Kepčija R., Primc-Habdija B. \& Habdija I., 2011: Seasonal and fine-scale spatial drift patterns in tufa-depositing barrage hydrosystem. Fundamental Applied Limnology 178, 131-145.

Sørensen, T., 1948: A method of establishing groups of equal amplitude in plant sociology based on similarity of species content // Kongelige Danske Videnskabernes Selskab. Biol. krifter. 5, 1-34.

Srdoč, D., Horvatinčić, N., Obelić, B., Krajcar, I. \& Sliepčević, A., 1985: Calcite deposition processes in karst waters with special emphasis on the Plitvice Lakes, Yugoslavia. Carsus Yugoslaviae 11, 101-204.

Stoffers, P., 1975: Recent carbonate sedimentation in the lakes of Plitvice (Yug.). Neues Jahrbuck fur Minéralogie 9, 412-418.

Svenson, B. W., 1972: Flight periods, ovarian mutation, and mating in Trichoptera at a South Swedish strean. Oikos 23, 370-383.

Szivák, I., Mikes, T., Szalontai, B., Kučinić, M., Vučković, I., Vadkerti, E., Kisfali, P., Pauls, S.U. \& BÁLINT, M., 2017: Ecological divergence of Chaetopteryx rugulosa species complex (Insecta, Trichoptera) linked to climatic niche diversification. Hydrobiologia 794, 31-47.

ŠAšıć, M., 2004: Inventarizacija vrsta roda Maculinea i prijedlozi za zaštitu njihovih staništa na području Nacionalnog parka Plitvička jezera. Plitvički bilten (Radovi), 6, 71-82.

ŠEgulJA, N. \& HRŠAK, V., 1994: Some floristic and ecological characteristics of association Bromo-Plantaginetum mediae Ht. (31) 49 on permanent plot No. 82 (National Park Plitvice Lakes - Croatia). Plant Ecology 110, 103-114.

Š́mničKi, P., Previšić, A., Ivković, M., Čmrlec , K. \& Mihaljević, Z. 2011: Emergence of caddisflies (Trichoptera, Insecta) at lakes and tufa barriers in the Plitvice Lakes National Park. Entomologia Croatica 15, 145-161.

ŠemničKi, P., Previšić, A., Ivković, M., Čmrlec, K. \& Mihaljević, Z., 2012: Tufa Barriers from a Caddisfly's Point of View: Streams or Lake Outlets? Internatinal review of Hydrobiology 97, 465-484.

Špoljar, M. \& Habdija, I. \& Primc-Habdija, B., 2007a: The Influence oft he Lotic and Lentic Strerches on the Zooseston Flux throught the Plitvice Lakes (Croatia). Annales de Limnologie 43, 29-40.

Šroljar, M., Primc-Habdija, B. \& Habdija, I., 2007b: Transport of seston in the karstic hydrosystem of the Plitvice Lakes (Croatia). Hydrobiologia 579, 199-209.

Šтамвuк-Giljanović, N., 2006: Vode Dalmacije. Medicinski fakultet Sveučilišta u Splitu, Split, 588 pp,

Vilenica, M., Ivković, M., SARtori, M. \& Mihaljević Z., 2017a: Mayfly emergence along an oligotrophic Dinaric karst hydrosystem: spatial and temporal patterns, and species-environment relationship. Aquat Ecology 51, 417-433. DOI 10.1007/s10452-017-9626-3

Vilenica, M., Mičetić Stanković, V., Sartori, M., Kučinić, M. \& Mihaljević, Z., 2017b: Environmental factors affecting mayfly assemblages in tufa-depositing habitats of the Dinaric Karst. Knowledge and Management of Aquatic Ecosystems 418, 1-14.

Vitecek, S., Graf, W., Previšić, A., Kučinić, M., Oláh, J., Bálint, M., Keresztes, L., Pauls, S.U. \& WaRINGER, J. 2015: A hairy case: The evolution of filtering carnivorous Drusinae (Limnephilidae, Trichoptera). Molecular Phylogenetic and Evolution 93, 249-260. 
Vitecek, S., Kučinić, M., Previšić, A., Živić, I., Stojanović, K., Keresztes, L., Bálint, M., Hoppeler, F., WARINGER, J., GraF, W. \& PAULS, U. S., 2017: Integrative taxonomy by molecular species delimitation : multi-locus data corroborate a new species of Balkan Drusinae microendemics. BMC Evolutionary Biology. 17 DOI 10.1186/s12862-017-0972-5

VUČKović, I., 2011: Faunistic, taxonomic and ecological characteristics of caddisflies (Insecta:Trichoptera) on the cachment area of the River Cetina. PhD Thesis, Faculty of Science, University of Zagreb, Zagreb, $176 \mathrm{pp}$.

VučKović, I., Previšić, A. Graf, W. \& Kučrnić, M. 2011: Description of the female and distribution of Annitella apfelbecki Klapálek, 1899 (Insecta: Trichoptera). Aquatic Insects 33, 381-389.

Wallace, I. D., Wallace, B. \& Philipson, G. N., 1990: A key to the Case-bearing Caddis larvae of Britain and Ireland. Freshwater Bioilogical Association, Kendal, 237 pp.

WAGNER, R. \& Sснмidt, H. H., 2004: Yearly discharge patterns determine species abundance and community diversity: Analysis of a 25 year record from the Breitenbach. Archiv füf Hydrobiologie 161, 511-540.

WARINGER, J. \& GRAF, W., 1997: Atlas der Österreichischen Köcherfliegenlarven. Facultus Universitätsverlag, Wien, $286 \mathrm{pp}$.

WARINGer, J. \& Graf, W., 2011: Atlas der mitteleuropäischen Köcherfliegenlarven - Atlas of Central European Trichoptera Larvae. Erik Mauch Verlag, Dinkelscherben, 468 pp.

WARINGER, J. A., 1996: Phenology and abundance of Ephemeroptera, Plecoptera and Trichoptera caught by emergence traps at the Weidlingbach near Vienna, Austria. Int. Revue ges. Hydrobiol. 81, 63-77.

Waringer, J., Graf, W., Kučinić, M., Previšić, A. \& VučKović, I. 2009: The Larva and life cycle of Annitella apfelbecki Klapalek, 1899, including a re-description of Melampophylax nepos McLachlan, 1880 (Trichoptera: Limnephilidae). Aquatic insects 31, 71-80.

Waringer, J., Graf, W., Bálint, M., Kučinić, M., Pauls, S.U., Previšić, A., Kereszztes, L., Ibrahimi, H., ŽiviĆ, I., BJELANOvić, K., KRPAČ, V. \& ViteceK, S., 2015: Larval morphology and phylogenetic position of Drusus balcanicus, D. botosaneanui, D. serbicus and D. tenellus (Trichoptera: Limnephilidae: Drusinae). European Journal of Entomology 112, 344-361.

Wiberg-Larsen, P., Brodersen, K. P., Birkholm, S., Grøn, P.N. \& Skriver, J., 2000: Species richness and assemblage structure of Trichoptera in Danish streams. Freshwater Biology 43, 633-647.

Wood, P. J., Agnew, M. D. \& Petts, G. E., 2000: Flow variations and macroinvertebrate community responses in a small groundwater-dominated stream in south-east England. Hydrol. Process 14, 31333147.

ZwICKER, G. \& J. RUBINIC, 2005. Water level fluctuations as an indicator of tufa barrier growth dynamics in the Plitvice Lakes. Materials and Geoenvironment 52, 161-163.

Žutinić, P., Gligora Udovič, M., Kralj Borojević, K., Plenković-Moraj, A. \& Padosák, J., 2014: Morphofunctional classifications of phytoplankton assemblages of two deep karstic lakes. Hydrobiologia 740, 146-166. DOI: 10.1007/s10750-014-1950-1 
Appendix. Systematic list of caddisflies with localities, dates, sex and collecting method (investigations from 1997, 2000 and 2001).

Family Rhyacophilidae

Rhyacophila aurata Brauer, 1857

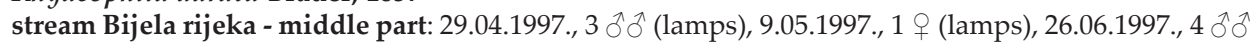
(lamps), 22.07.1997., $1 \hat{\jmath}$ (lamps), 16.08.1997., $1 \hat{\jmath}, 4$ 우 (lamps), 2.09.1997., $2 \hat{\jmath} \hat{\sigma}^{\lambda}$ (lamps), 14.09.1997. 1 $\hat{\delta}$ (lamps), 5.10.1997., 1 $\hat{\delta}, 2$ 우 (lamps), 20.10.1997., 3 $\widehat{\jmath}$ (lamps); stream Crna rijeka-middle part: 4.07.1997., 1 q (lamps), 2.09.1997., 1 o (lamps), 14.09.1997., 1 ô, 1 ㅇ (lamps); stream Plitvica - lower

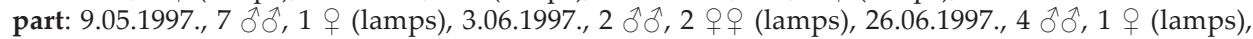

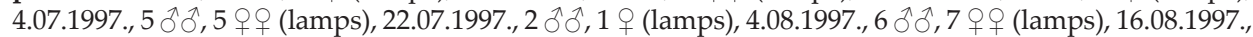

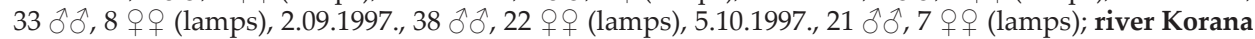

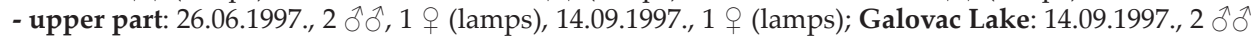

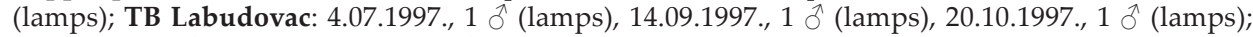
30.09.2000., 1 ô (EPT), 31.08.2001., 1 ठ (EPT), 2.10.2001., 1 ㅇ (EPT), 2.11.2001., 3 우우 (EPT); TB Kozjak/ Milanovac: 3.06.1997., 1 ㅇ (lamps), 2.11.2001., 1 ㅇ (EPT); TB Novakovića Brod: 3.06.1997., 1 ô (lamps), 14.09.1997., 1 ㅇ (lamps), 20.10.1997., 1 ठ, 2 우 (lamps)

\section{Rhyacophila dorsalis plitvicensis Kučinić \& Malicky, 2002}

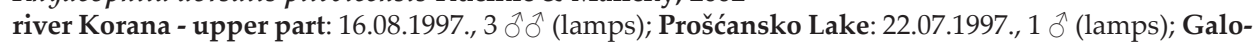

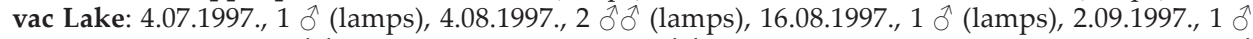

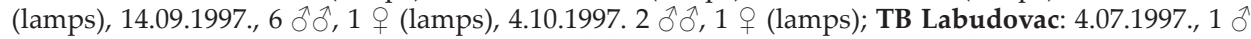

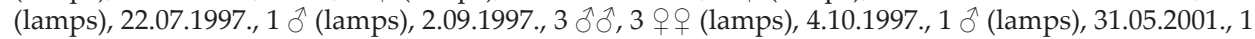
i (EPT), 30.06.2001., 1 ㅇ (EPT), 31.07.2001., 1 ㅇ (EPT), 31.08.2001., 1 ô, 1 ㅇ (EPT), 2.10.2001., 10 우

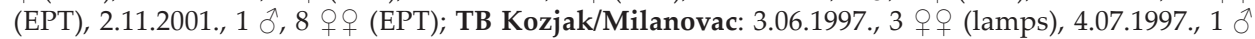
(lamps), 4.VIII.1997. 1 ㅇ (lamps), 16.08.1997., 1 ð (lamps), 2.09.1997., 1 o (lamps), 14.09.1997., 8 우 (lamps), 2.10.2001., 1 † (EPT), 2.11.2001., 1 † (EPT); TB Novakovića Brod: 4.07.1997., 1 ô (lamps),

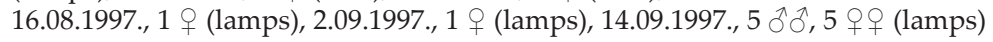

\section{Rhyacophila fasciata Hagen, 1859}

spring of Bijela rijeka: 17.05.1997., 1 (lamps), 3.06.1997., 2 ô (lamps), 26.06.1997., 1 ภ (lamps),

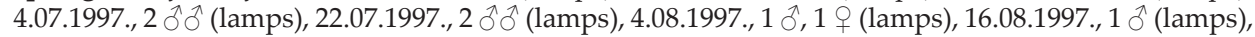

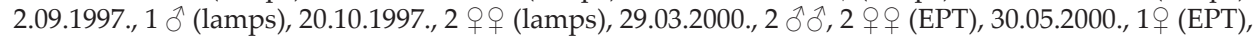
29.08.2000., 1 우 (EPT), 15.09.2000., 1 o (EPT), 16.10.2000. 1 우 (EPT), 28.10.2000., 1 ㅇ (EPT), 27.11.2000.,

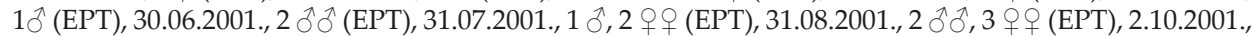

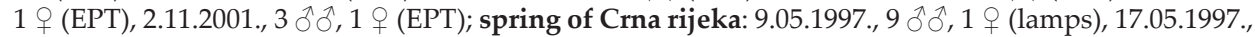

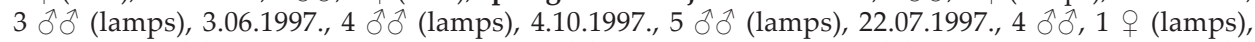

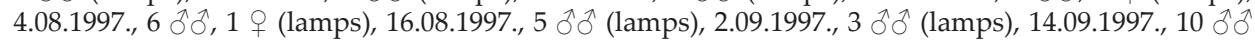

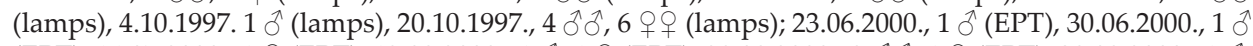

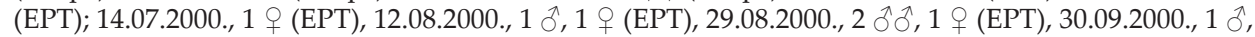

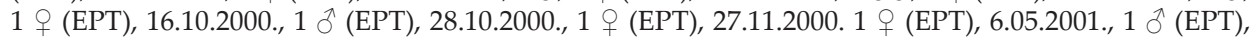

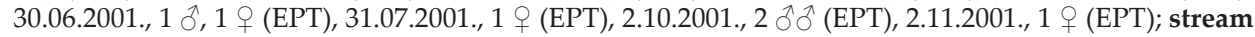

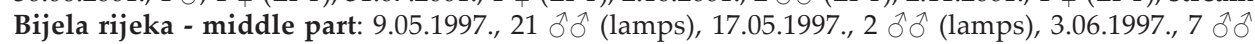

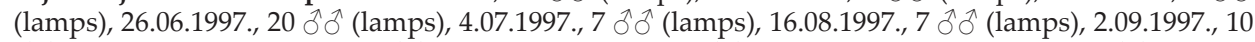
ठิठ stream Crna rijeka - middle part: 29.04.1997., $5 \hat{\partial} \hat{\partial}$ (lamps), 3.06.1997., $1 \hat{\partial}$ (lamps), 4.07.1997., $1 \hat{\delta}$

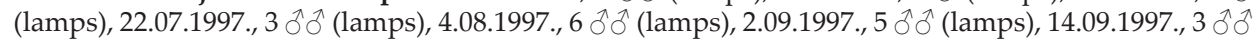

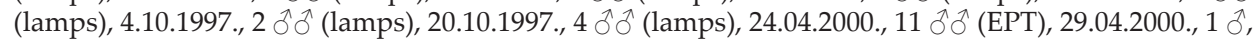

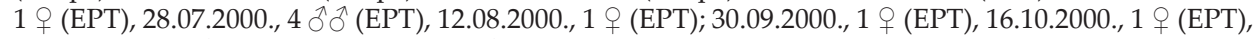
27.11.2000., 1 o (EPT), 2.10.2001., 1 ○े (EPT), 2.11.2001., 1 क (EPT); stream Plitvica - lower part: 26.06.1997., 2 ơ (lamps), 16.08.1997., 1 q (lamps), 2.09.1997., 1 oे, 1 q (lamps), 5.10.1997., 1 q (lamps); TB Labudovac: 22.07.1997., 1 ๙ (lamps), 14.09.1997., 1 ๙ (lamps)

Rhyacophila schmididinarica Urbanič, Krušnik \& Malicky, 2000 spring of Crna rijeka: 22.07.1997., 1 ô (lamps)

\section{Rhyacophila tristis Pictet, 1834}

spring of Crna rijeka: 4.07.1997., 1 ㅇ (lamps), 23.06.2000., 1 § (EPT), 30.06.2000., 1 우 (EPT), 14.07.2000., 1 ㅇ (EPT), 28.07.2000., 1 (EPT); stream Bijela rijeka - middle part: 9.05.1997., 1 ภ, 1 ㅇ (lamps), 


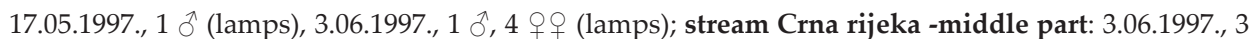

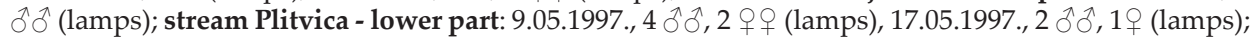
river Korana - upper part: 3.06.1997., 2 ठิ่ $\hat{0}, 7$ 우 (lamps); Galovac Lake: 26.06.1997., 1 o (lamps), 4.07.1997., 1 우 (lamps); TB Labudovac: 20.05.2000., 6 ơ (EPT); TB Novakovića Brod: 3.06.1997., 3 우 (lamps)

Family Glossosomatidae

Synagapetus krawanayi Ulmer, 1938

spring of Bijela rijeka: 9.06.2000., 1 ô (EPT), 30.06.2001., 1 ㅇ (EPT), 31.07.2001., 1 우 (EPT), 2.10.2001., 1

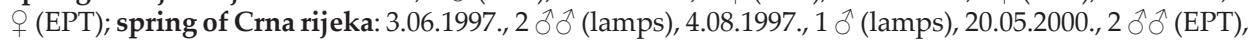

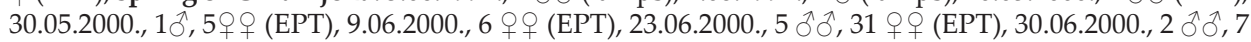

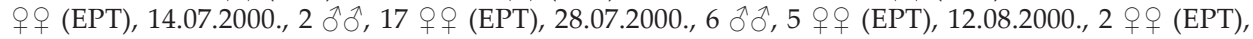

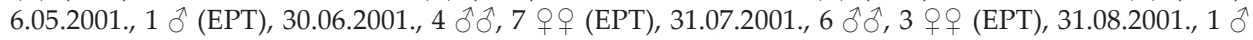
(EPT); stream Bijela rijeka - middle part: 3.06.1997., 3 o 0 (lamps); stream Crna rijeka - middle part:

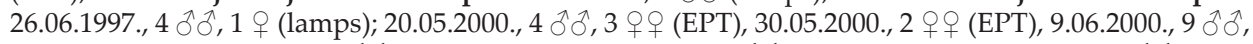

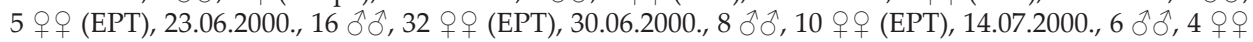

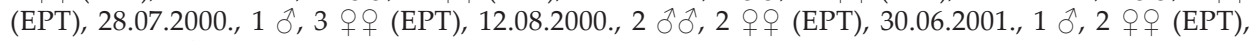
31.07.2001., 1 해, 2 우우 (EPT)

Glossosoma bifidum McLachlan, 1879

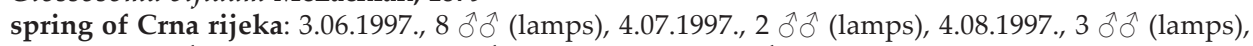
14.09.1997., 1 ô (lamps), 30.05.2000., 1 के (EPT), 30.06.2001., 1 ô (EPT)

Glossosoma discophorum Klapálek, 1902

spring of Bijela rijeka: 9.05.1997., 1 ô (lamps), 22.07.1997., 1 ô (lamps), 4.08.1997., 1 ô, 2 q ㅇ (lamps),

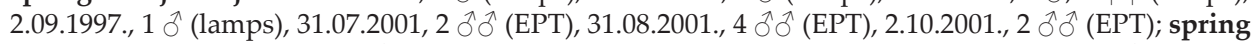
of Crna rijeka: 4.07.1997., 1 o (lamps); stream Bijela rijeka - middle part: 3.06.1997., 1 ô (lamps),

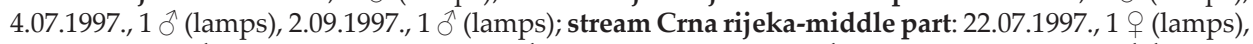
14.09.1997., 1 ภे (lamps), 23.06.2000., 1 के (EPT), 14.07.2000., 1 के (EPT), 12.08.2000., 2 के के (EPT), 29.08.2000., 1 के (EPT), 31.08.2001., 1 के (EPT)

Glossosoma sp. (female)

spring of Bijela rijeka: 4.07.1997., 1 ( (lamps), 22.07.1997., 1 q (lamps), 4.08.1997., 2 우 (lamps), 2.09.1997 23.06.2000., 1 q (EPT), 30.09.2000., 1 \& (EPT), 28.10.2000., 1 q (EPT), 30.06.2001., 14 q $q$ (EPT), 31.07.2001., 18 우우 (EPT), 31.08.2001., 8 우우 (EPT); spring of Crna rijeka: 4.07.1997., 1 우 (lamps), 2.09.1997., 1 q (lamps), 14.09.1997., 1 ㅇ (lamps), 30.05.2000., 1 ㅇ (EPT), 9.06.2000., 2 우 (EPT), 23.06.2000., 2 우 (EPT), 30.06.2000., 1 ㅇ (EPT), 14.07.2000., 1 \& (EPT); stream Crna rijeka - middle part: 22.07.1997., 1 ( lamps), 30.06.2000., 1 ㅇ (EPT), 12.08.2000., 1 \& (EPT), 29.08.2000., 1 q (EPT), 31.07.2001., 2 우 (EPT)

Family Philopotamidae

Philopotamus montanus (Donovan, 1813)

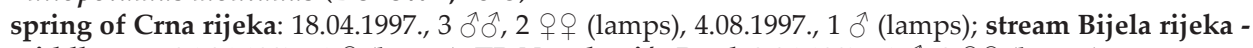
middle part: 26.06.1997., 1 q (lamps); TB Novakovića Brod: 3.06.1997., 1 §̊, 3 q $q$ (lamps)

Philopotamus variegatus (Scopoli, 1763)

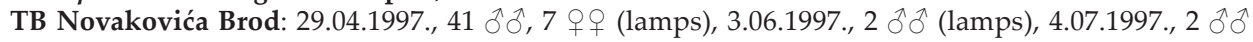
(lamps)

Wormaldia cf. occipitalis (Pictet, 1834) (subterranea Radovanović, 1932)

stream Crna rijeka - middle part: 4.07.1997., 2 $\widehat{\partial}$ (lamps); river Korana - upper part: 3.06.1997., 2 $\widehat{\delta}$

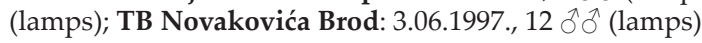

Wormaldia subnigra McLachlan, 1865

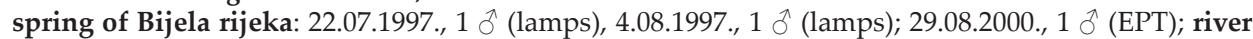

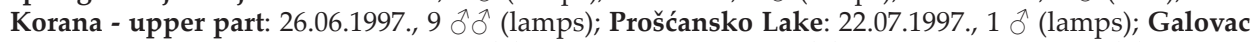
Lake: 3.06.1997. (lamps), 4.07.1997., 30 ơ

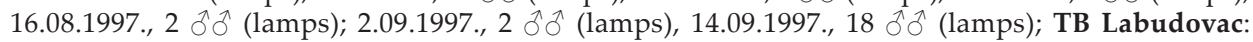

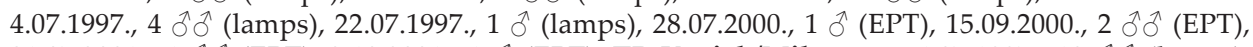

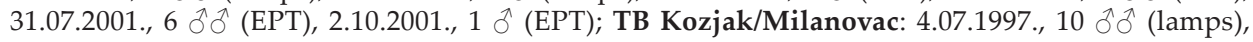




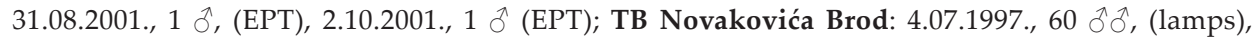

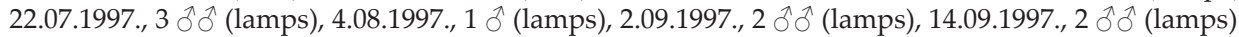

Wormaldia sp. (females)

spring of Bijela rijeka: 22.07.1997., 6 우 (lamps); river Korana - upper part: 3.06.1997., 1 ( lamps), Galovac Lake: 3.06.1997., 7 우 (lamps), 4.07.1997., 9 우 (lamps), 22.07.1997., 1 q (lamps), 14.09.1997., 3 우오 (lamps); TB Labudovac: 14.07.2000., 2 우오 (EPT), 28.07.2000., 6 우오 (EPT), 12.08.2000., 4 우우 (EPT), 15.09.2000., 1 우 (EPT), 31.07.2001., 2 우우 (EPT), 31.08.2001., 3 우우 (EPT), 2.10.2001., 3 우우 (EPT), 2.11.2001., 1 ㅇ (EPT); TB Kozjak/Milanovac: 4.07.1997., 2 우 (lamps), 31.08.2001., 1 q (EPT); TB Novakovića Brod: 3.06.1997., 4 우우 (lamps), 4.07.1997., 18 우우 (lamps), 22.07.1997., 1 우 (lamps), 20.10.1997., 3 우이기

Family Polycentropodidae

Cyrnus trimaculatus (Curtis, 1834)

spring of Bijela rijeka: 22.07.1997., 1 o (lamps); river Korana - upper part: 4.08.1997., $17 \hat{\delta} \widehat{\delta}, 3$ 우우

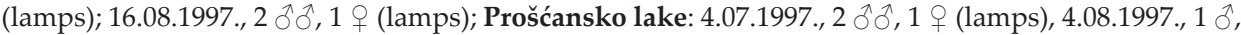

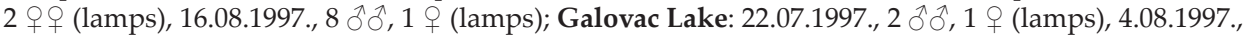

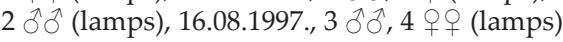

Neureclipsis bimaculata (Linnaeus, 1758)

TB Labudovac: 14.07.2000., 1 ô (EPT), 31.07.2001., 2 우 (EPT), 2.10.2001., 1 ㅇ (EPT); TB Kozjak/Milanovac: 31.08.2001., 1 ○े (EPT), 2.10.2001., 4 우우 (EPT)

Plectrocnemia brevis McLachlan, 1878

spring of Bijela rijeka: 4.08.1997., 2 우 (lamps); spring of Crna rijeka: 17.05.1997., 1 스 (lamps),

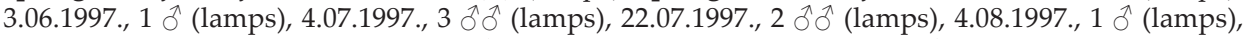

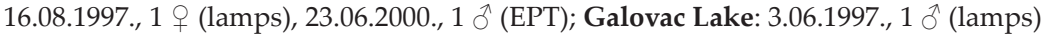

Plectrocnemia conspersa (Curtis, 1834)

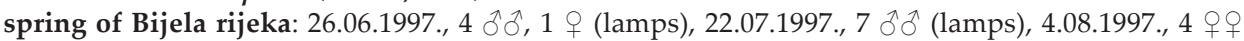
(lamps); spring of Crna rijeka: 16.08.1997., 1 ㅇ (lamps); stream Crna rijeka - middle part: 4.07.1997.,

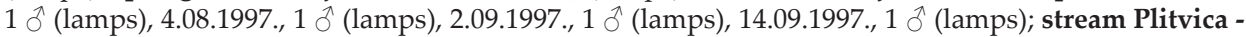
lower part: 16.08.1997., 1 o (lamps); river Korana - upper part: 7.05.1997., 1 ㅇ (lamps); Galovac Lake: 4.07.1997., 1 ô (lamps); Kozjak Lake: 2.09.1997., 1 ô (lamps); TB Labudovac: 16.08.1997., 1 q (lamps)

Polycentropus excisus Klapálek, 1894

Galovac lake: 3.06.1997., 2 के $\hat{o}, 1$ \& (lamps)

Polycentropus flavomaculatus (Pictet, 1834)

spring of Bijela rijeka: 22.07.1997., $2 \widehat{\partial}$ (lamps); stream Plitvica - lower part: 9.05.1997., $2 \widehat{\partial}, 1$ ㅇ

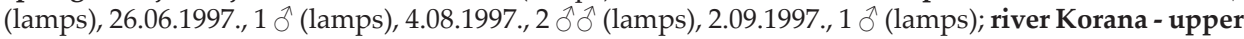
part: 3.06.1997., 3 के के (lamps), 26.06.1997., 11 के (lamps), 14.09.1997., 3 के (lamps); Galovac Lake:

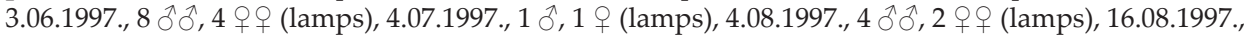

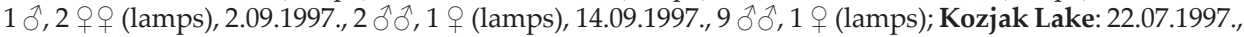
1 ㅇ (lamps); TB Labudovac: 12.08.2000., 1 이 1 q (EPT), 31.05.2001., 1 ㅇ (EPT), 30.06.2001., 2 우 (EPT), 2.10.2001., 2 우 (EPT); TB Kozjak/Milanovac: 3.06.1997., 1 ○ิ (lamps); TB Novakovića Brod: 4.08.1997.,

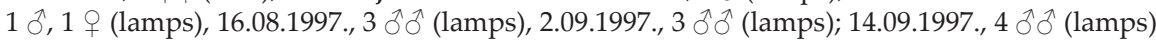

Polycentropus schmidi Novak \& Botosaneanu, 1965

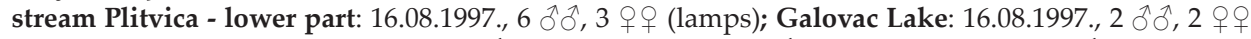
(lamps); TB Labudovac: 22.07.1997., 1 ô (lamps), 4.08.1997., 1 ô (lamps), 16.08.1997., 1 ô (lamps); TB

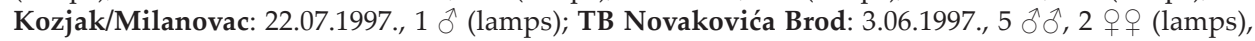

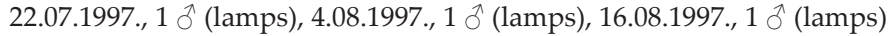

Family Psychomyidae

Lype phaeopa (Stephens, 1836)

Galovac Lake: 3.06.1997., 1 ๙ै (lamps) 
Lype reducta (Hagen, 1868)

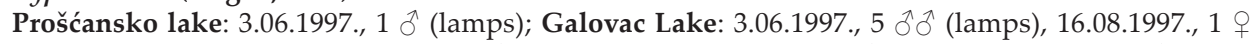

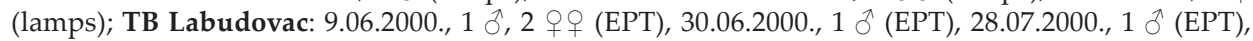

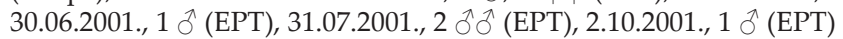

Psychomyia klapaleki Malicky, 1995

stream Plitvica-lower part: 26.06.1997., $2 \precsim \hat{\jmath}$ (lamps)

Tinodes dives (Pictet, 1834)

spring of Bijela rijeka: 9.05.1997., 1 q (lamps), 3.06.1997., 3 ふふふ, 21 우 (lamps), 26.06.1997., 1 ふ, 5 우

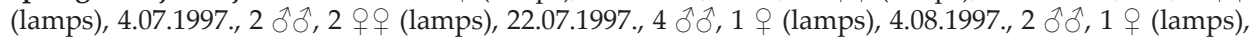

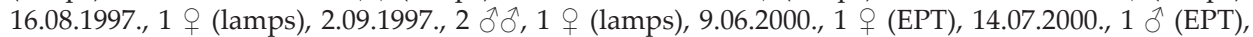

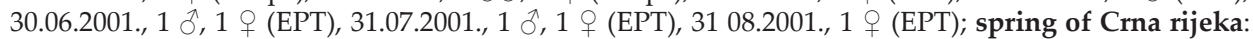

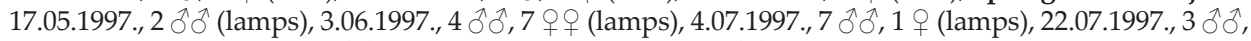

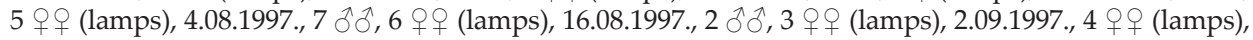

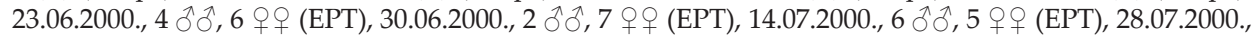

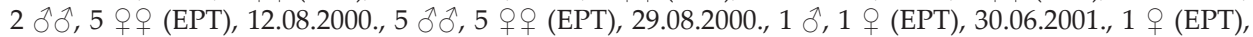

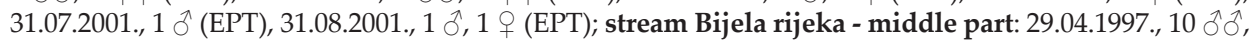

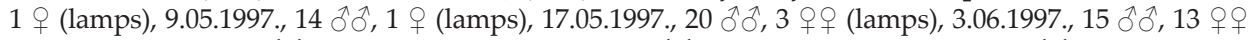

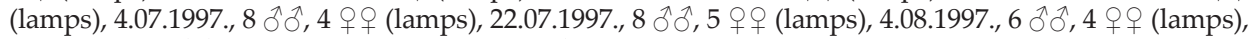

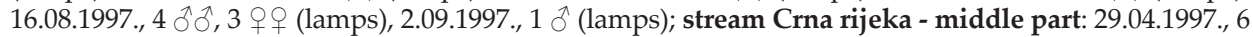

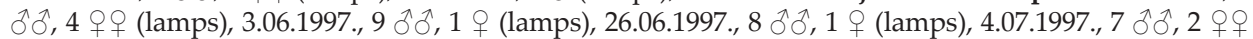

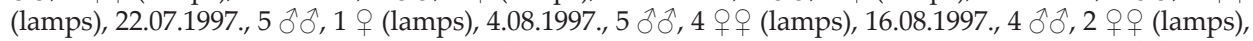

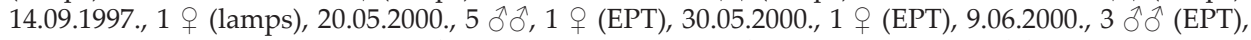

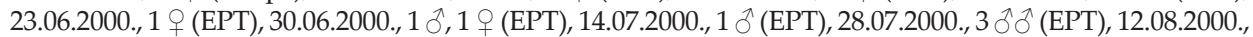

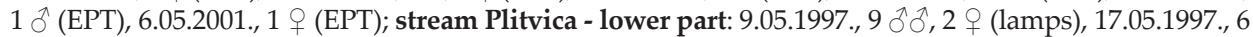

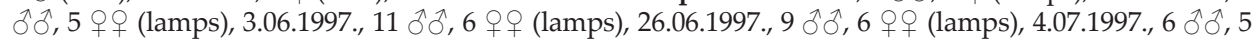

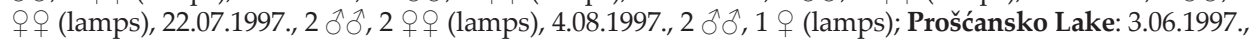
1 đิ (lamps); TB Labudovac: 31.05.2001., 1 ㅇ (EPT)

Tinodes unicolor (Pictet, 1834)

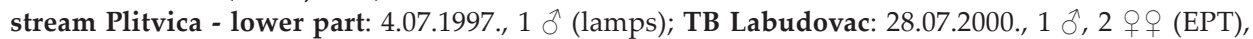
31.07.2001., 1 ふै (EPT)

Tinodes waeneri (Linnaeus, 1758)

spring of Bijela rijeka: 3.06.1997., 3 $q$ ㅇ (lamps); Prošćansko lake: 16.08.1997., $9 \widehat{\jmath} \widehat{\jmath}$ (lamps), 14.09.1997.,

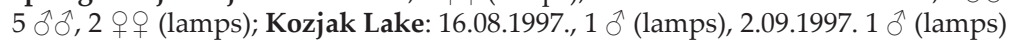

Family Hydropsychidae

Hydropsyche incognita Pitsch, 1993

stream Plitvica - lower part: 16.08.1997., 1 (lamps); river Korana - upper part: 2.09.1997., $2 \hat{\delta}$ (lamps); TB Kozjak/Milanovac: 3.06.1997., 1 đ(lamps)

\section{Hydropsyche instabilis (Curtis, 1834)}

stream Bijela rijeka - middle part: 4.08.1997., 1 đ (lamps); stream Plitvica - lower part: 26.06.1997., 3 $\hat{\partial} \hat{\partial}$ (lamps), 4.07.1997., $3 \hat{\partial} \hat{\partial}$ (lamps), 4.08.1997., $2 \hat{\partial} \hat{\partial}$ (lamps); river Korana-upper part: 16.08.1997. 1

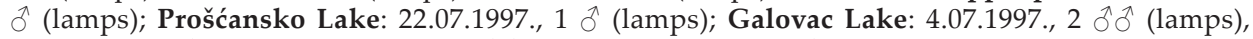

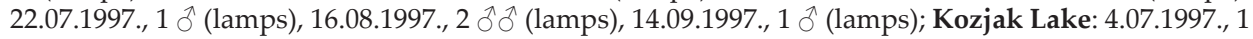

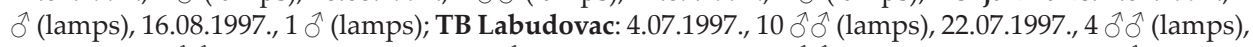

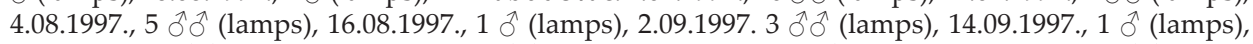

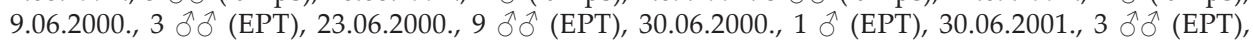

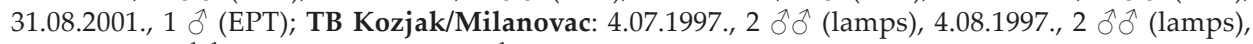

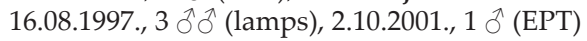

\section{Hydropsyche saxonica McLachlan, 1884}

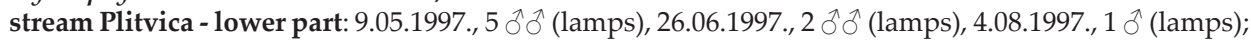

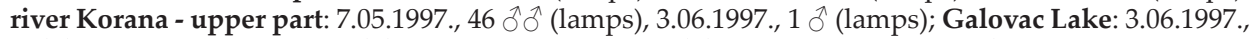

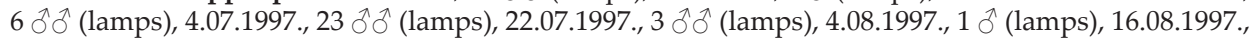

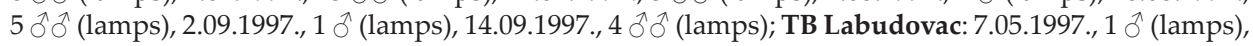




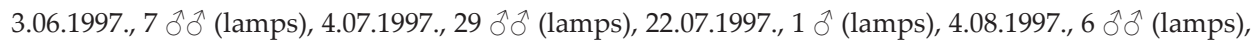

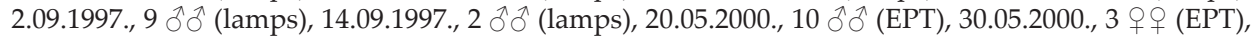

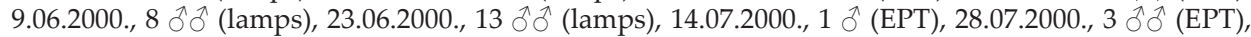

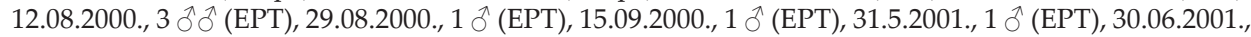

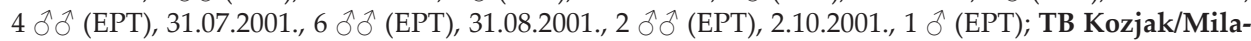

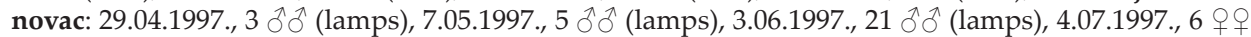
(lamps), 22.07.1997., $3 \hat{\partial} \hat{\partial}$ (lamps), 4.08.1997., $2 \hat{\partial}$ (lamps), 16.08.1997., $3 \hat{\partial} \hat{\partial}$ (lamps), 2.09.1997., $7 \hat{\partial}$

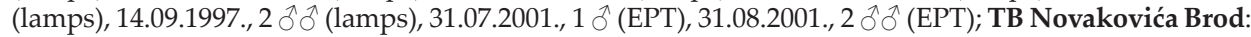

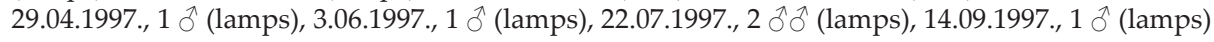

Hydropsyche sp. (female)

stream Bijela rijeka - middle part: 4.08.1997., 3 우 (lamps); stream Crna rijeka - middle part: 22.07.1997., 1 ㅇ (lamps): stream Plitvica - lower part: 9.05.1997., 3 우 우 (lamps), 26.06.1997., 4 우 (lamps), 4.07.1997., 3 우우 (lamps), 4.08.1997., 5 우아 (lamps), 16.08.1997., 3 우우 (lamps), 2.09.1997., 1 우 (lamps); river Korana - upper part: 7.05.19917., 5 우우 (lamps), 3.06.1997., 2 우우 (lamps); 26.06.1997., 3 우우 (lamps), 4.07.1997., 1 q (lamps); Prošćansko Lake: 4.07.1997., 1 q (lamps), 4.07.1997., 1 + (lamps); Galovac Lake: 3.06.1997., 2 우 (lamps), 4.07.1997., 11 우 (lamps), 22.07.1997., 2 우 (lamps), 4.08.1997., 2 우 (lamps), 16.08.1997., 3 우 (lamps), 2.09.1997., 1 q (lamps), 14.09.1997., 2 우 (lamps); Kozjak Lake: 26.06.1997., 1 우 (lamps), 4.07.1997., 9 우우 (lamps); 22.07.1997., 3 우우 (lamps), 4.08.1997., 13 우우 (lamps), 16.08.1997., 2 우 (lamps), 2.09.1997., 2 우 (lamps); TB Labudovac: 3.06.1997., 3 우우 (lamps); 4.07.1997., 23 우 (lamps), 22.07.1997., 60 우우 (lamps), 4.08.1997., 47 우우 (lamps), 16.08.1997., 23 우우 (lamps), 2.09.1997., 8 우우 (lamps), 14.09.1997., 1 앙 (lamps), 20.05.2000., 28 우 (EPT), 30.05.2000., 6 우우 (EPT), 9.06.2000., 11 우아 (EPT), 23.06.2000., 11 우우 (EPT), 28.07.2000., 5 우우 (EPT), 12.08.2000., 5 우아 (EPT), 29.08.2000., 4 우우 (EPT), 15.09.2000., 1 우 (EPT), 30.09.2000., 2 우우 (EPT), 31.05.2001, 3 우우 (EPT), 30.06.2001., 15 우우 (EPT), 31.07.2001., 11 우우 (EPT), 31.08.2001., 2 우우 (EPT), 2.10.2001., 3 우우 (EPT); TB Kozjak/Milanovac: 7.05.1997., 42 우우 (lamps), 3.06.1997., 37 우우, 4.07.1997., 84 우우 (lamps), 22.07.1997., 127 우우 (lamps), 4.08.1997., 84 우우 (lamps), 16.08.1997., 41 우우 (lamps), 2.09.1997., 25 우우 (lamps), 14.09.1997., 7 우우 (lamps), 31.08.2001., 2 오오 (EPT); TB Novakovića Brod: 29.04.1997., 1 ㅇ (lamps), 3.06.1997., 6 우오 (lamps), 4.07.1997., 6 우우 (lamps), 22.07.1997., 1 우 (lamps), 16.08.1997., 1 ㅇ (lamps), 2.09.1997. 3 우우 (lamps), 14.09.1997., 6 우우 (lamps)

Family Phryganeidae

Agrypina varia (Fabricius, 1793)

stream Crna rijeka - middle part: 4.07.1907., 1 (lamps); stream Plitvice - lower part: 16.08.1997., 1 ठ

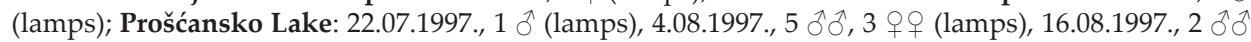

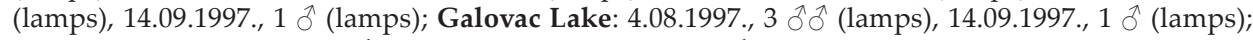
Kozjak Lake: 4.08.1997., 1 ô, 1 ㅇ (lamps), 16.08.1997., 1 ô (lamps); TB Labudovac: 4.08.1997., 1 우 (lamps), 16.08.1997., 1 ô, 1 q (lamps); TB Kozjak/Milanovac: 4.07.1997., 1 ㅇ (lamps), 4.08.1997., 3 đo

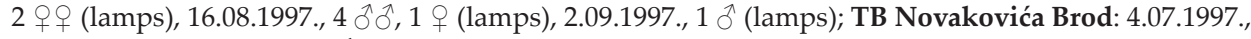
1 ㅇ (lamps), 22.07.1997., 1 ô (lamps)

Phryganea bipunctata Retzius, 1783

Prošćansko Lake: 3.06.1997., 1 ô (lamps)

Phryganea grandis Linnaeus, 1758

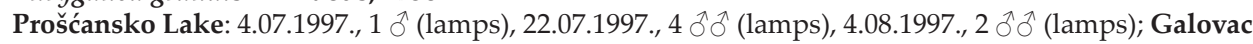

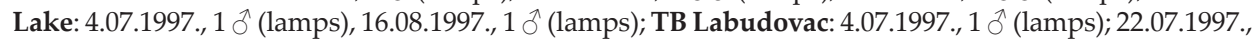
$1 \hat{\jmath}$ (lamps)

Family Goeridae

Goera pilosa (Fabricius, 1775)

Kozjak Lake: 3.06.1997., 6 ô ô 6 (lamps)

Litax niger (Hagen, 1859)

spring of Bijela rijeka: 20.05.2000., $1 \widehat{\partial}$ (EPT), spring of Crna rijeka: 9.05.1997., $12 \lambda \widehat{\partial}, 3$ 우 (lamps),

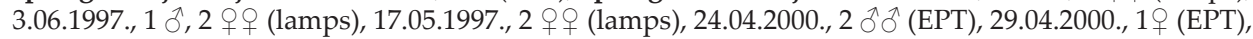

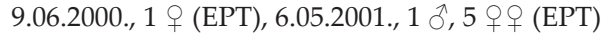


Silo pallipes (Fabricius, 1781)

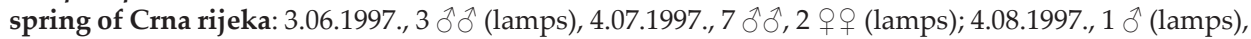

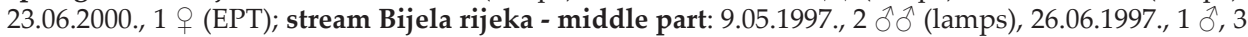
우우 (lamps), 4.08.1997., 1 ○े (lamps); stream Crna rijeka - middle part: 4.07.1997., $1 \hat{\jmath}$ (lamps), 23.06.2000.,

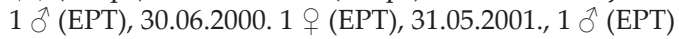

Family Lepidostomatidae

Lepidostoma hirtum (Fabricius, 1775)

spring of Bijela rijeka: 3.06.1997., 1 (lamps), 26.06.1997., 1 क (lamps), 22.07.1997., 1 ô (lamps); stream Plitvica - lower part: 3.06.1997., 1 q (lamps); Prošćansko Lake: 3.06.1997., 1 \& (lamps), 4.07.1997., 2 + $ᄋ$ (lamps); Galovac Lake: 3.06.1997., 3 đô (lamps); Kozjak Lake: 26.06.1997., 1 ㅇ (lamps), 4.07.1997., 4 우우 (lamps), 22.07.1997., 1 우 (lamps), 14.09.1997., 1 아 (lamps); TB Labudovac: 3.06.1997., 2 시, 31 우우

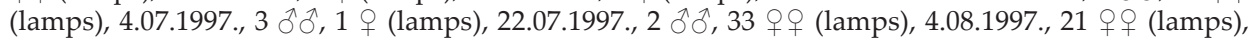

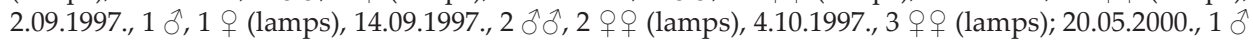

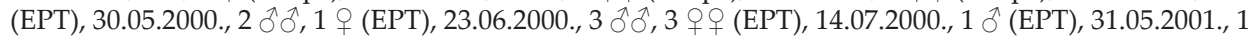

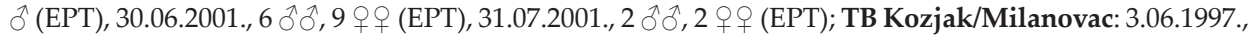

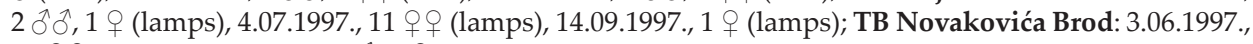
92 우 (lamps); 4.07.1997., 1 ô, 1 ㅇ (lamps)

Family Limnephilidae

Drusus croaticus Marinković, 1971

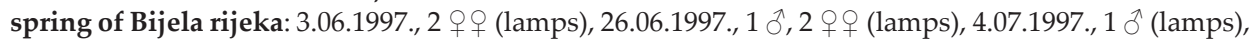

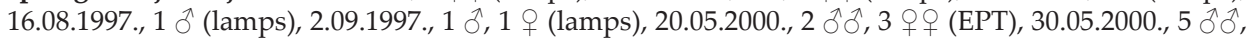

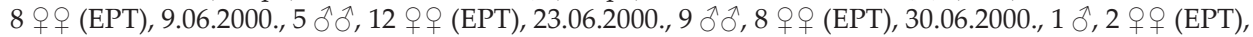

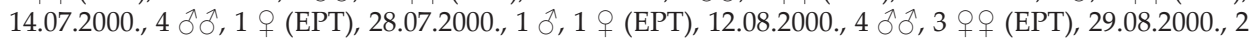

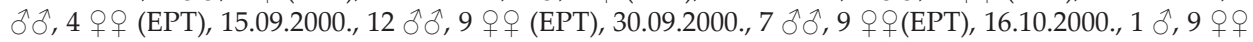
(EPT), 28.10.2000., 4 우우 (EPT), 27.11.2000., 3 우우 (EPT), 30.06.2001., 13 해스, 38 우우 (EPT), 31.07.2001., 3

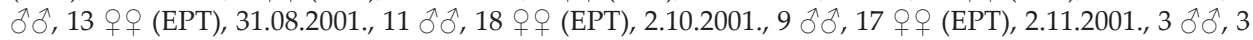

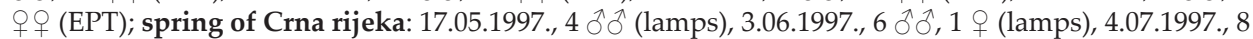

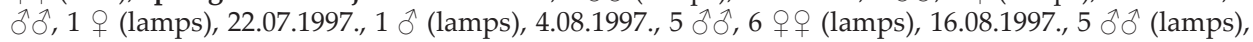

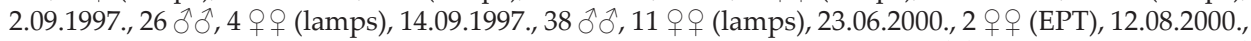

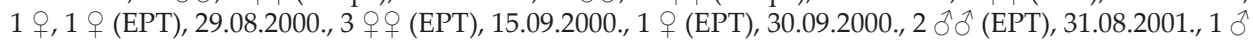

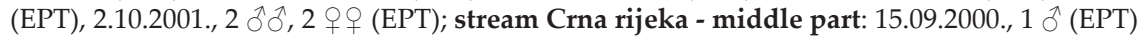

Rhadicoleptus alpestris (Kolenati, 1848)

river Korana-upper part: 7.05.1997., 1 ○े (lamps)

Limnephilus affinis Curtis, 1834

spring of Crna rijeka: 9.05.1997., $1 \hat{\jmath}$ (lamps)

Limnephilus auricula Curtis, 1834

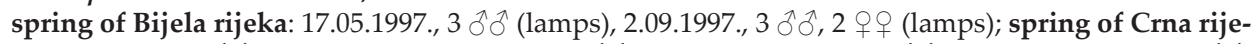

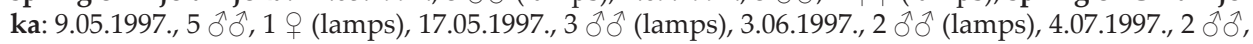
1 ㅇ (lamps), 14.09.1997., 2 우 (lamps); stream Bijela rijeka - middle part: 9.05.1997., 4 o $\widehat{\partial}$ (lamps),

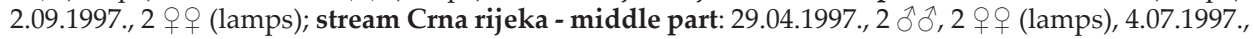
$1 \delta$ (lamps); stream Plitvice - lower part: 9.05.1997., $1 \hat{\jmath}$ (lamps), 26.06.1997., $1 \hat{\jmath}$ (lamps)

Limnephilus extricatus McLachlan, 1865

stream Bijela rijeka - middle part: 26.06.1997., 1 đ (lamps); Prošćansko Lake: 16.08.1997., 1 đ (lamps)

Limnephilus flavicornis (Fabricius, 1787)

spring of Crna rijeka: 22.07.1997., $1 \hat{\jmath}$ (lamps), 4.08.1997., $1 \hat{\jmath}$ (lamps); TB Labudovac: 2.09.1997., 1 ㅇ (lamps)

Limnephilus hirsutus (Pictet, 1834)

spring of Bijela rijeka: 2.09.1997., 1 ○े (lamps); stream Plitvica - lower part: 2.09.1997., 1 ô (lamps) 
Limnephilus ignavus McLachlan, 1865

spring of Bijela rijeka: 16.08.1997., 6 (lamps); stream Bijela rijeka - middle part: 2.09.1997., 1 (lamps); stream Crna rijeka - middle part: 14.09.1997., 1 $え$ (lamps); Galovac Lake: 14.09.1997., $1 \precsim$ (lamps)

\section{Limnephilus lunatus Curtis, 1834}

stream Bijela rijeka - middle part: 5.10.1997., 1 ð (lamps); stream Crna rijeka - middle part: 14.09.1997., 1 ㅇ (lamps), 2.11.2001., 1 đ (EPT); stream Plitvica - lower part: 26.06.1997., 1 ๆ (lamps), 16.08.1997., 6

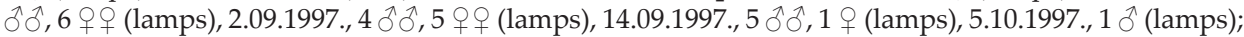
river Korana - upper part: 3.06.1997., 4 우 (lamps); Prošćansko Lake: 3.06.1997., 1 đ (lamps), 4.07.1997.,

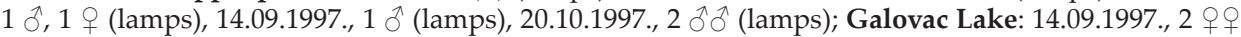
(lamps); Kozjak Lake: 4.07.1997., 1 ô, 1 ㅇ (lamps), 4.08.1997., 1 ở, 2.09.1997., 1 q (lamps); TB Labudo-

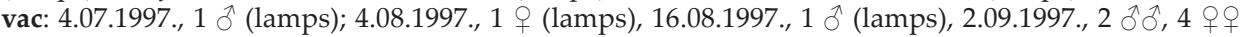
(lamps), 14.09.1997., 1 ㅇ (lamps), 9.06.2000., 1 ỏ, 3 우 (EPT), 23.06.2000., 1 ㅇ (EPT), 30.06.2000., 1 우

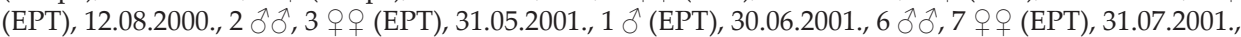

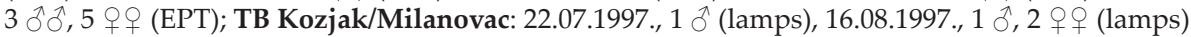

Limnephilus rhombicus (Linnaeus, 1758)

spring of Bijela rijeka: 4.08.1997., $1 \hat{\jmath}, 1$ (lamps); stream Bijela rijeka - middle part: 16.08.1997., 1 $\widehat{\delta}$ (lamps), 2.09.1997., $1 \hat{\delta}, 1$ (lamps); stream Crna rijeka - middle part: 4.07.1997., $2 \hat{\jmath}$ (lamps),

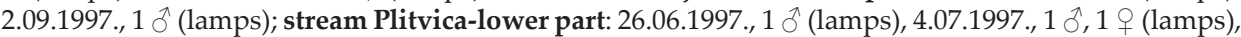
16.08.1997., 2 우 (lamps), 2.09.1997., 2 우 (lamps); river Korana - upper part: 3.06.1997., 3 우 (lamps); Prošćansko Lake: 3.06.1997., 2 우 (lamps), 4.07.1997., 1 đ (lamps), 22.07.1997., 1 q (lamps), 4.08.1997.,

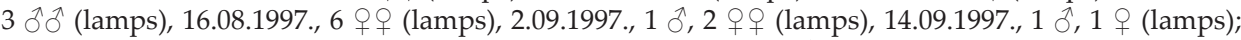
Galovac Lake: 4.07.1997., 1 \& (lamps); Kozjak Lake: 4.07.1997., 1 ○े (lamps), 16.08.1997., 3 \& (lamps), 14.09.1997., 1 q (lamps); TB Labudovac: 22.07.1997., 1 ㅇ (lamps), 4.08.1997., 5 우 (lamps), 16.08.1997.,

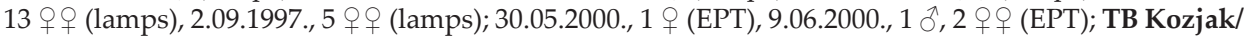

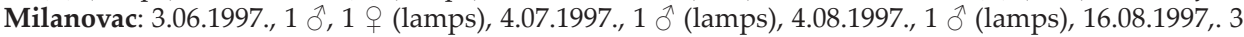

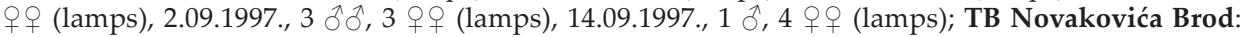
2.09.1997., 1 ㅇ (lamps), 14.9.1997., 1 ๆ (lamps)

Limnephilus sparsus Curtis, 1834

spring of Bijela rijeka: 2.09.1997., $2 \hat{\jmath}, 1$ q (lamps); stream Crna rijeka - middle part: 4.08.1997., $1 \precsim$

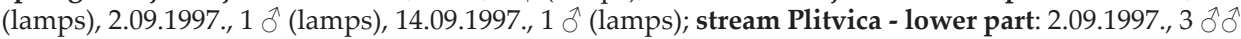
(lamps); river Korana - upper part: 14.09.1997., 3 우 (lamps); Kozjak Lake: 14.09.1997., 1 q (lamps);

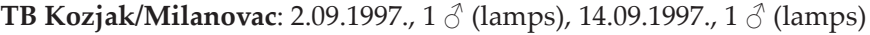

Chaetopteryx fusca Brauer, 1857

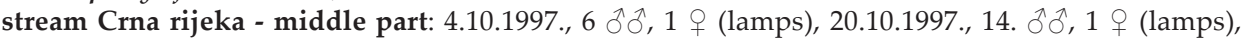

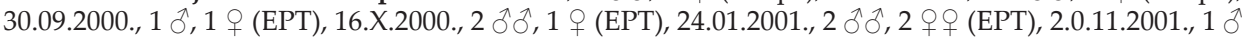
(EPT).; Prošćansko Lake: 20.10.1997., $5 \hat{\jmath} \hat{\jmath}, 3$ 우 (lamps)

Chaetopteryx gonospina Marinković, 1966

spring of Crna rijeka: 14.09.1997., $1 \precsim$ (lamps), 15.09.2000., $1 \lesssim$ (EPT)

Grammotalius nigropunctatus (Retzius, 1783)

spring of Crna rijeka: 9.05.1997., 2 우 (lamps), 3.06.1997., 1 ภ, 1 ㅇ (lamps), 22.07.1997., 1 (lamps), 23.06.2000., 1 † (EPT); stream Bijela rijeka - middle part: 9.05.1997., $1 \hat{\jmath}$ (lamps), 3.06.1997., $1 \hat{\jmath}$ (lamps), 26.06.1997., $1 \lesssim$ (lamps), 4.07.1997., $1 \lesssim$ (lamps); stream Crna rijeka-middle part: 28.07.2000., $1 \delta$ (EPT); stream Plitvice - lower part: 9.05.1997., 1 \% (lamps)

Glyphotaelius pellucidus (Retzius, 1783)

spring of Crna rijeka: 9.05.1997., $1 \hat{\jmath}, 2$ 우 (lamps); stream Crna rijeka - middle part: 4.07.1997. 1 우 (lamps), 22.07.1997., 1 đิ (lamps); stream Plitvica - lower part: 22.07.1997., 1 đै (lamps), 2.09.1997., 3 우 (lamps); river Korana - upper part: 14.09.1997., 1 đ (lamps); Prošćansko Lake: 3.06.1997., $1 \precsim$ (lamps),

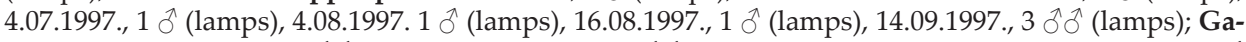

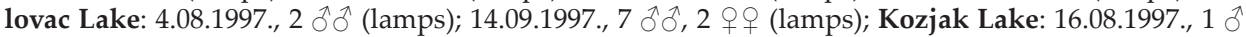

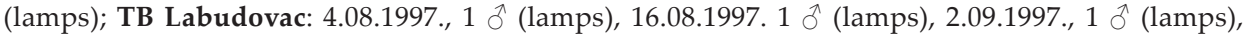




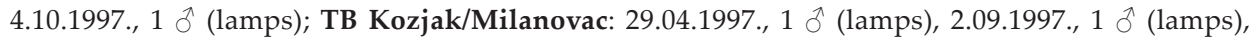
14.09.1997., 3 $\widehat{\jmath}, 2$ 우 (lamps); TB Novakovića Brod: 3.06.1997., 1 ㅇ (lamps), 4.08.1997., 1 $\Uparrow$ (lamps),

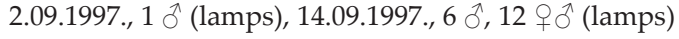

Micropterna lateralis Stephens, 1837

stream Crna rijeka - middle part: 31.05.2001., $1 \curvearrowright$ (EPT)

Micropterna nycterobia McLachlan, 1875

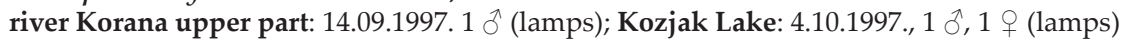

Micropterna sequax McLachlan, 1875

stream Bijela rijeka - middle part: 14.09.1997., 1 ㅇ (lamps); ); river Korana upper part: 3.06.1997. 1 우

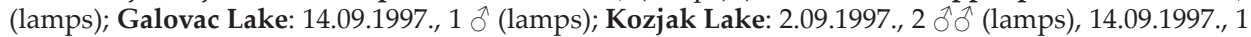

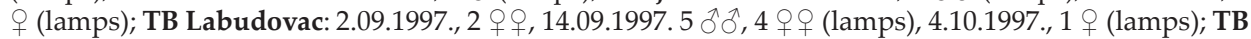
Kozjak/Milanovac: 14.09.1997., 2 우 (lamps), 4.10.1997., 1 q (lamps)

Stenophylax permistus McLachlan, 1875

spring of Bijela rijeka: 9.05.1997., $3 \precsim \widehat{\jmath}$ (lamps), 17.05.1997., $1 \precsim$ (lamps), 4.08.1997., $1 \precsim$ (lamps); spring of Crna rijeka: 9.05.1997., $3 \hat{\jmath}, 1$ (lamps); stream Bijela rijeka - middle part: 9.05.1997., $1 \hat{\jmath}$ (lamps); stream Crna rijeka - middle part: 29.04.1997., $1 \hat{\jmath}, 3$ 우 (lamps); stream Plitvica: 9.05.1997., $1 \precsim$ (lamps);

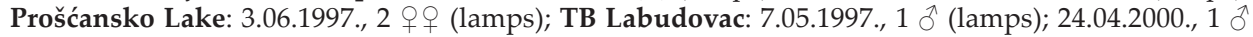
(EPT); ТB Kozjak/Milanovac: 29.04.1997,. 1 ઈ̋, 2 우 (lamps), 7.05.1997., 1 q (lamps), 2.09.1997., $1 \hat{\jmath}$ (lamps), 4.10.1997., 1 ઈ, 1 ㅇ (lamps)

Stenophylax vibex (Curtis, 1834)

spring of Bijela rijeka: 9.05.1997. 1 (lamps)

Potamophylax latipennis (Curtis, 1834)

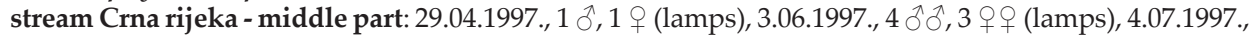

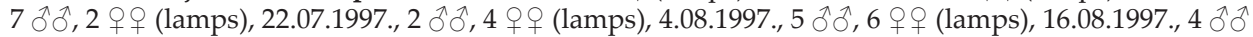

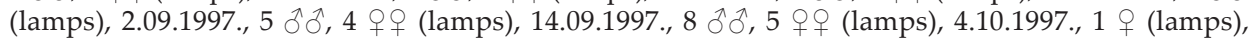
20.10.1997., 1 ઈ (lamps), 31.05.2001., 1 ㅇ (EPT); stream Plitvica - lower part: 14.09.1997., $1 \hat{\jmath}$ (lamps); Prošćansko Lake: 16.08.1997., 1 (lamps)

Potamophylax nigricornis (Pictet, 1834)

spring of Bijela rijeka: 3.06.1997., 4 우 (lamps), 26.06.1997., 1 (lamps); spring of Crna rijeka: 3.06.1997., $1 \hat{\sigma}, 1$ (lamps), 4.07.1997., 1 (lamps), 30.06.2001., 1 o , 1 q (EPT); stream Bijela rijeka middle part: 14.09.1997., 1 q (lamps); stream Crna rijeka-middle part: 9.06.2000., $1 \lesssim$ (EPT)

Potamophylax pallidus (Klapálek, 1899)

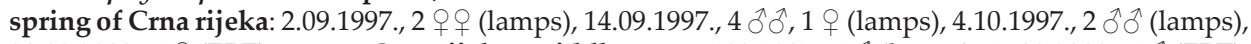

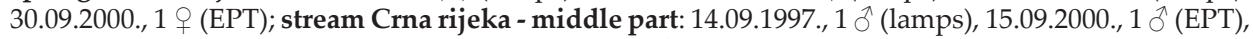
2.10.2001., 1 q (EPT); Galovac Lake: 14.09.1997., 1 §̊, 1 q (lamps); TB Labudovac: 14.09.1997., 1 ㅇ

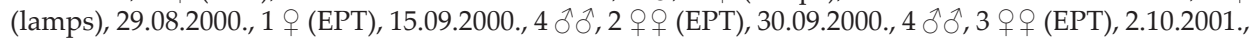

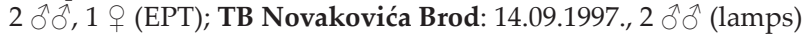

Potamophylax rotundipennis (Brauer, 1857)

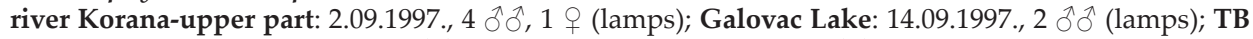

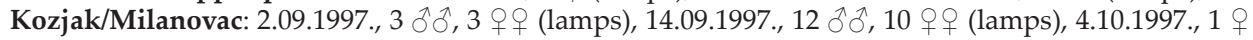

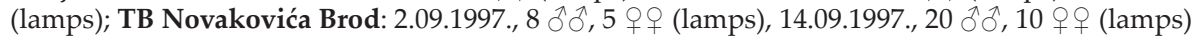

Allogamus uncatus (BRAUER, 1857)

spring of Bijela rijeka: 30.09.2000., 1 \& (EPT), 2.10.2001., $6 \hat{\jmath}, 9+q$ (EPT); spring of Crna rijeka:

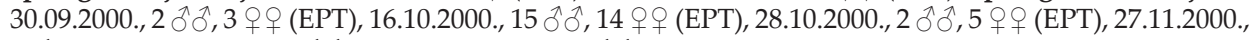

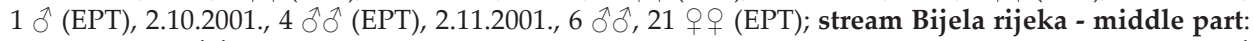

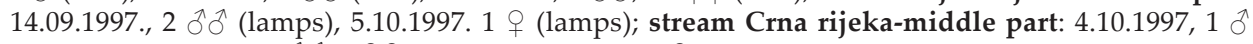

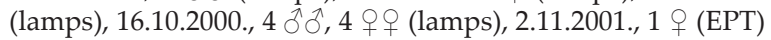


Halesus digitatus (Schrank, 1781)

stream Bijela rijeka - middle part: 14.09.1997., 16 우우 (lamps), 5.10.1997., 1 §̋, 3 우아 (lamps); stream

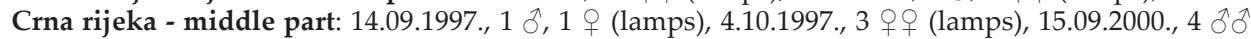
(EPT), 30.09.2000., 1 o, 1 क (EPT); stream Plitvica - lower part: 14.09.1997., 1 ㅇ (lamps), 5.10.1997., 1 ,

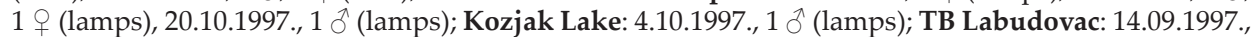

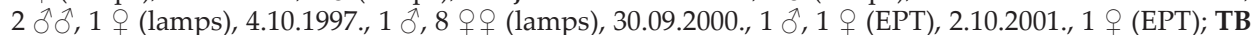

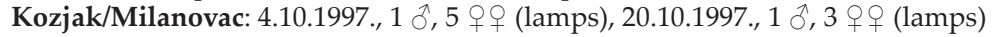

Halesus tesselatus (Rambur, 1842)

spring of Bijela rijeka: 14.09.1997., 1 우 (lamps); Kozjak Lake: 4.10.1997., 10 새, 2 우우 (lamps); TB

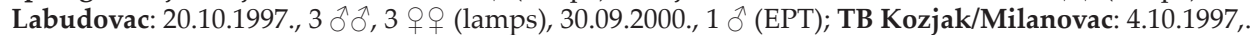

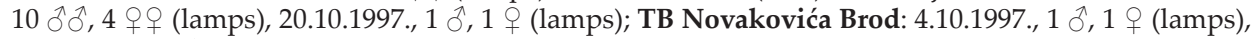
20.10.1997., 1 oे (lamps)

Hydatophylax infumatus (McLachlan, 1865)

stream Plitvica - lower part: 3.06.1997., 10 , 1 q (lamps)

Family Sericostomatidae

Notidobia ciliaris (Linnaeus, 1761)

TB Labudovac: 31.05.2001., 1 ऊิ (EPT)

Sericostoma flavicorne Schneider, 1845

spring of Bijela rijeka: 3.06.1997., 1 q (lamps); spring of Crna rijeka: 4.07.1997., 1 ( (lamps), 20.05.2000.,

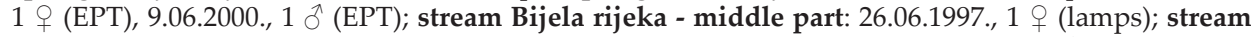
Crna rijeka - middle part: 30.05.2000., 1 \& (EPT), 23.06.2000., 1 क (EPT), 30.06.2001., 1 o (EPT); stream Plitvica: 26.06.1997., $2 \hat{\jmath} \hat{\jmath}, 6$ 우 (lamps), 4.07.1997., 1 ô (lamps); river Korana - upper part: 3.06.1997.,

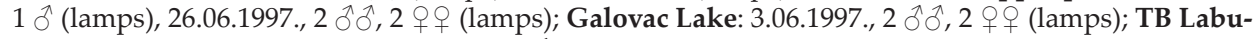
dovac: $30.05 .2000 ., 1$ क (EPT), 9.06.2000., 1 ○े (EPT)

Family Odontoceridae

Odontocerum albicorne (Scopoli, 1763)

stream Bijela rijeka - middle part: 26.06.1997., 1 \& (lamps); stream Crna rijeka - middle part: 4.07.1997.,

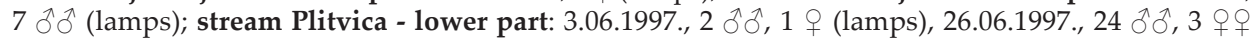

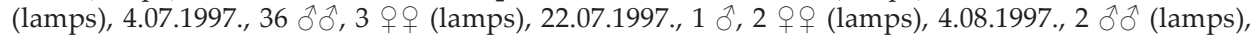
16.08.1997., 1 ㅎํ, 2 우우 (lamps)

Family Beraeidae

Beraea pullata (Curtis, 1834)

stream Crna rijeka - middle part: 3.06.1997., 1 (lamps)

Beraeamyia schmidi Botosaneanu, 1960

river Korana - upper part: 4.07.1997., 2 ơ (lamps); TB Novakovića Brod: 3.06.1997., 1 q (lamps)

Family Leptoceridae

Adicella filicornis (Pictet, 1834)

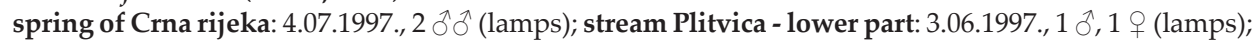
river Korana - upper part: 4.07.1997., 1 \& (lamps)

Adicella syriaca Ulmer, 1907

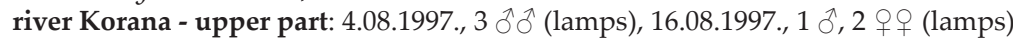

Mystacides azurea (Linnaeus, 1761)

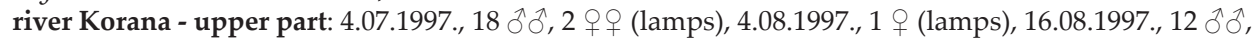
4 우우 (lamps), 14.09.1997., 1 우 (lamps); Galovac Lake: 22.07.1997., 1 ㅇ (lamps); Kozjak Lake: 3.06.1997.,

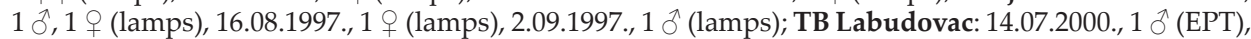

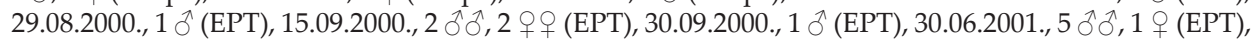


31.07.2001., 4 $\widehat{\jmath}, 2$ 우우 (EPT), 31.08.2001., 1 우 (EPT); TB Kozjak/Milanovac: 31.08.2001., 6 우 (EPT); TB Novakovića Brod: 3.06.1997., 9 $\widehat{\partial}, 7$ 우 (lamps), 4.07.1997., 3 우 (lamps)

Mystacides nigra (Linnaeus, 1758)

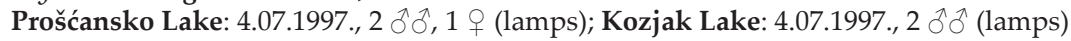

Athripsodes aterrimus (Stephens, 1836)

spring of Bijela rijeka: 4.08.1997., 1 q (lamps); Prošćansko Lake: 4.07.1997., 1 đ , 1 q (lamps), 4.08.1997.,

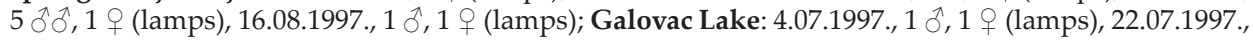
1 đ (lamps); Kozjak Lake: 4.08.1997., 1 + (lamps); TB Labudovac: 4.07.1997., 1 + (lamps); TB Novakovića Brod: 4.07.1997., 2 के कें (lamps)

Athripsodes bilineatus (Linnaeus, 1758)

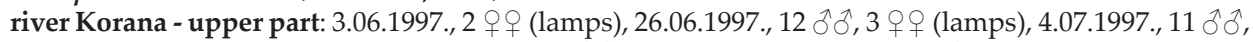

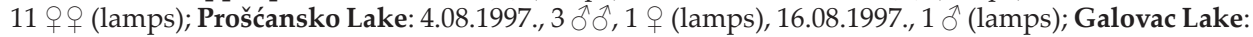

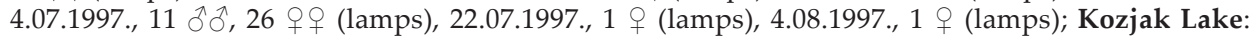

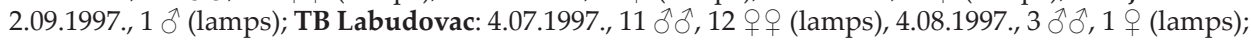

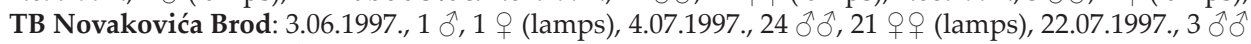
(lamps), 16.08.1997., 1 §ै (lamps)

\section{Athripsodes cinereus (Curtis, 1834)}

spring Bijela rijeka: 4.08.1997., 2 우 우 (lamps); stream Plitvica - lower part: 16.08.1997., 1 아 (lamps);

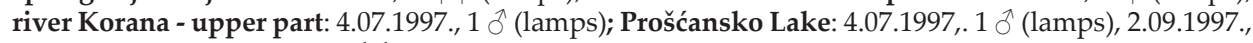
1 q (lamps), 14.09.1997., 3 ổ, 1 q (lamps); Galovac Lake: 4.07.1997., 2 우 (lamps); Kozjak Lake:

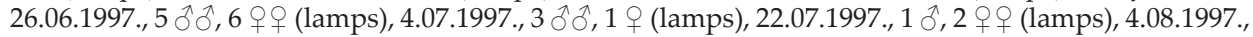

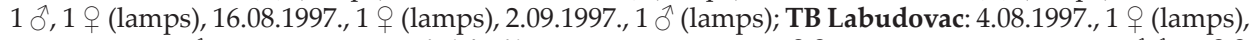

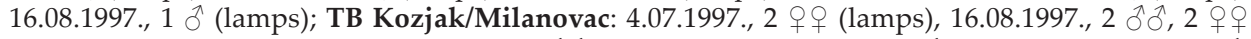

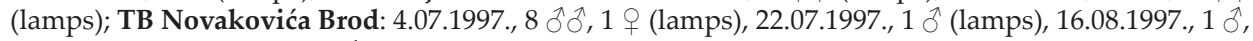
2 우 (lamps), 2.09.1997., 1 § (lamps)

Ceraclea dissimilis (Stephens, 1836)

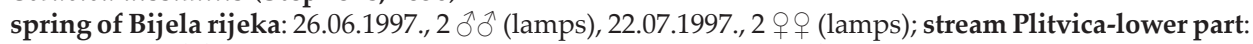
4.07.1997., 2 ô ô, 2 우 (lamps); Prošćansko Lake: 4.07.1997., 1 ô (lamps), 14.09.1997., 1 q (lamps); Kozjak Lake: 26.06.1997., 1 (lamps), 4.07.1997., 1 ô (lamps), 4.08.1997., 2 ô (lamps); TB Labudovac:

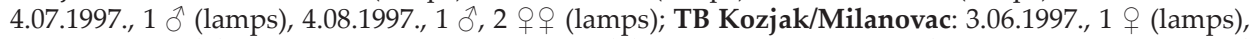

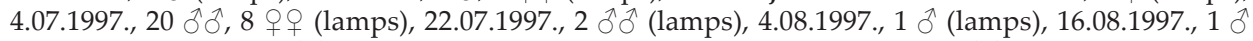

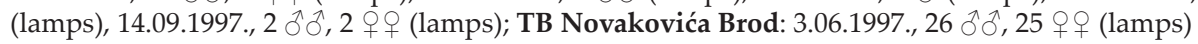

Oecetis testacea (Curtis, 1834)

spring Bijela rijeka: 22.07.1997., 1 q (lamps); Prošćansko Lake: 4.07.1997., 2 ô (lamps); Galovac Lake:

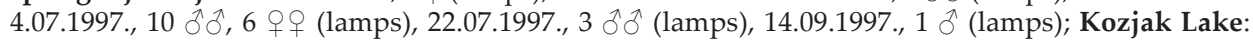

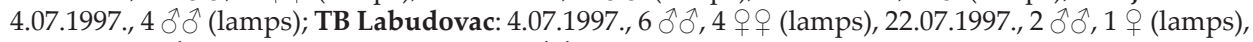
4.08.1997., 1 ô, 4 우우 (lamps), 2.09.1997., 6 저 (lamps), 23.06.2000., 1 우 (EPT); TB Kozjak/Milanovac:

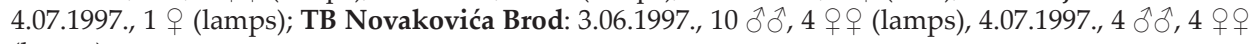
(lamps) 